\title{
BEHAVIOR OF R.C. COLUMNS CONTAINING ALKALI WASTES OF OIL AND CELLULOSE PAPER INDUSTRIES AND EXPOSED TO SULFATE AND CHLORIDE ATTACK UNDER AXIAL STATIC LOADS
}

\author{
Rashwan M. M, Mahmoud H. A, Aly G. A. and Abo Elfadel M. Megahd \\ Civil Engineering Department, Faculty of Engineering, Assiut University, Assiut, \\ Egypt
}

(Received April 1, 2006 Accepted May 30, 2006)

The underground R.C. structures especially footings, piers, piles and column necks are always subjected to aggressive environmental conditions during their exploatation. These conditions are represented by the aggressive sulfate and chloride attack from surrounded soil or underground water. Which implies to deterioration of concrete cover and penetration of sulfate and chloride ions to the interior of concrete elements. According to that, the actual strength of R.C. elements decreases and corrosion damage of embedded steel bars accompanied with large deformations of concrete and steel increases. Consequently, a higher reduction of the construction durability occurs. So, the need for using an effective and economic admixtures for the protection of concrete elements against sulfate and chloride attack is required.

Therefore, the main purpose of the project described in this paper is to study experimentally the mechanism effect of the suggested economic admixtures, which fabricated from alkali wastes of oil and cellulose paper industries, on the behavior of normal strength R.C. columns, subjected to external sulfate and chloride attack, under axial static loads. The main variables studied in this research on fifeteen R.C. columns were: three different types of plasticizing organic admixtures(SM-S, CM-B \&SM-O), which contain in their compositions amount of alkali wastes from secondary products of oil and cellulose paper industries plus a control plasticizing admixture (Addicrete DM2), and three different concentrations of external surrounded sulfate and chloride solutions $\left(2 \% \mathrm{Na}_{2} \mathrm{SO}_{4}+1 \% \mathrm{CaCL}_{2} \quad-\right.$ Group $\quad A, \quad 4 \%$ $\mathrm{Na}_{2} \mathrm{SO}_{4}+2 \% \mathrm{CaCL}_{2}$ - Group B, and $6 \% \mathrm{Na}_{2} \mathrm{SO}_{4}+3 \% \mathrm{CaCL}_{2}$ - Group C).

The experimental results showed that, Ultimate loads, stiffness, deformations, mode of failure and properties of the failure zone of the different groups of R.C. tested columns are significantly affected by the suggested admixtures and the concentration of sodium sulfate and calcium chloride solutions. R.C. columns modified with these admixtures(SM-S, CM-B \&SM-O) and hardened in $6 \% \mathrm{Na}_{2} \mathrm{SO}_{4}+3 \% \mathrm{CaCL}_{2}$ until 7 months showed a higher increment in their ultimate and working loads by about 51, $41, \& 15 \%$, a large increase of their energy absorption and ductility index of about 90, $47 \& 33 \%$ over than that of the control column and a decrease of their ultimate longitudinal concrete strain by about 40, $24 \& 18 \%$, respectively compared to the control tested column without admixtures 
KEYWORDS: behavior, admixture, alkali wastes, strength, strain, concrete, lateral, longitudinal, sodium sulfate, calcium chloride, chemical attack, failure mechanism, ultimate load, cracking load.

\section{1- INTRODUCTION}

In general, concrete has a low resistance to chemical attack. There are several chemical agents which react with concrete, but two forms of attack are most common, namely, leaching and sulfate attack. Chemical agents essentially react with certain compounds of the hardened cement paste and the resistance of concrete to chemical attack therefore depends largely on the type of cement used. The resistance of concrete to chemical attack has improved with increase of its impermeability [1]. The general reactions involved in external sulfate attack have been described previously by Cohen and Bentur [2]. Sulfate attack on cement mortars or concrete leads to the conversion of hydrated products of cement to ettringite, gypsum and other phases, and also to the destabilization of the primary strength provided calcium silicate hydrate (C-SH) gel. The formation of ettringite and gypsum is common in cementitious materials exposed to most types of sulfate solutions. The expansion resulting from sulfate attack is generally attributed to the formation of these two compounds, although there is some controversy surrounding the exact mechanisms causing expansion [3]. When attacking solution contains magnesum ions, such as magnesium sulfate $\left(\mathrm{MgSO}_{4}\right)$, the formation of magnesium hydroxide (brucite) and conversion of C-S-H into magnesium silicate hydrate M-S-H were observed [4, 5].

When cement-based materials are exposed to sodium sulfate attack, gypsum and ettringite are produced by chemical reactions of sulfate and $\mathrm{Ca}(\mathrm{OH})_{2}, \mathrm{C}_{3} \mathrm{~A}$. Formation of gypsum plays an important role in the damage of materials [2, 6, 7]. There is a close relationship between $\mathrm{Ca}(\mathrm{OH})_{2}$ content and gypsum formation. Ettringite formation results in cracking and expansion of the material. Expansion is related to the water absorption of crystalline ettringite. So, it is necessary to increase the resistance of concrete against sulfate attack. Some researchers used pozzolanic, dolomite, fly ash, and silica fume materials in the technology of concrete for increase its resistance to sodium sulfate attacks. These materials react with $\mathrm{Ca}(\mathrm{OH}) 2$ and the result is additional CSH gel. This transformation leads to the increase of cement materials resistance to sodium sulfate attack [2, 8, 9, and 10].

Over the past several years, there has been a concerned research effort to explore the mechanism effect of chemical plasticizing admixtures, especially organic types, on the mechanical properties of R.C. structures. Increasing the concrete alkali content from $0.6 \%$ to $1.25 \%$ of $\mathrm{Na}_{2} \mathrm{O}_{\mathrm{e}}$ of the cement mass by adding alkali addition to mixing water has harmful effects on most mechanical properties (compressive, splitting, direct tensile, and flexure strengths) of concrete [11]. Admixtures, which contain in their compositions organic materials with limited doses, represent practical interest especially for our local country conditions. This practical interest attractive more investigators because of their availability and outstanding advantages such as: high compressive and tensile strength of concrete, durable concrete in aggressive environmental conditions, suitable resistance to corrosion, very low cost and not causing epidemic for organism of man $[12,13]$. 
The organic materials can be obtained from the secondary products and alkali wastes of vegetable oil, chemical synthesis and cellulose paper industries. The action of organic elements on cement paste and concrete mixture is determined by the structure of their molecules and correlation between organic and non-organic particles of their molecules. It is known that, organic elements have the ability of adsorption on the surfaces of cement particles and solid phase. They also take part in formation space, coagulate structure and orientation molecules. The initial development of producing concrete with organic admixtures technique took place in the USSR laboratories for materials testing and research, which have concentrated on the effect of organic materials on concrete properties since 1981. Many research works have been focused on the application of organic admixtures in the technology of concrete and reinforced concrete structures. Because of their positive influence on the physical and mechanical properties of R.C. elements not only on their early period of hardening, but also for the period of their exploitation in the building site $[12,13,14,15]$.

It is known that, the organic materials have not the solubility with water. So, in this research the solubility of these elements with water was achieved by using calcium oxide and superplasticizers such as "BVF" and "PVS". Investigations about using complex organic admixtures, which contain in their composition alkali wastes from oil industries, such as (LSM, CLSM, SMP) for the improvement of concrete and reinforced concrete properties were carried out [14, 15, 16, 17]. But, the mechanism effect of organic admixtures, containing alkali industrial wastes from oil and cellulose paper industries, on the resistance of R.C. elements against sulfate and chloride attack has not been enough studied. An experimental method for predicting the behavior of R.C. columns damaged by corrosion of steel under axial loads was carried out [18]. A numerical method for predicting the behavior of R.C. columns subjected to axial force and biaxial bending was proposed considering curvature localization [19].

So, this paper focuses on the experimental studies about the possibility of producing new chemical admixtures containing in their compositions alkali wastes from oil and cellulose paper industries, (type SM-S, SM-O \& CM-B). And then study their mechanism effect on the mechanical behavior and failure mechanism of square section R.C. columns of normal strength concrete of about $250-350 \mathrm{~kg} / \mathrm{cm}^{2}$, which were subjected to different concentrations of sulfate and chloride attack, under axial static loads. Experimental program consists of fifteen R.C. square section columns to propose the best-suggested admixture effect on their mechanical behavior under these aggressive environmential conditions.

\section{2- EXPERIMENTAL PROGRAM}

The main aim of this program is to investigate experimentally the behavior and failure mechanism of different groups of normal strength R.C. square columns modified with the new types of organic admixtures and exposed to different concentrations of sulfate and chloride solutions under static load. The experimental approaches in this study consist of testing fifteen square R.C. columns under static load. The main variables studied were:

- different types of suggested organic admixtures, which were fabricated in the laboratory and contained in their composition alkali wastes of oil and cellulose paper industries (type: SM-S, CM-B \& SM-O). 
- different concentrations of surrounded sulfate and chloride salt solutions ( type: $\mathrm{Na}_{2} \mathrm{SO}_{4}+\mathrm{CaCL}_{2}$ ).

All groups of columns, with and without admixtures, were identical in size, $15 \times 15 \mathrm{~cm}$ square section and overall height $(150 \mathrm{cms})$. They were casted in a vertical direction and hardened in fresh water conditions until 28-days. After that, they were immersed and hardened in different concentrations of sulfate and chloride solutions for a period of 7 months. Then, all groups of columns were tested under axial static load. All columns were divided into three groups, (group A, B \& C), depending on the amount of concentration of sulfate and chloride solutions. Each group consisted of 5 columns depending on the type of fabricated organic admixtures (SM-S, CM-B \& SM-O) and control plasticizing admixture (type $\mathrm{DM}_{2}$ ). The columns have the same amount of longitudinal reinforcement of $4 \varnothing 8 \mathrm{~mm}$ and stirrups of $7 \varnothing 6 \mathrm{~mm} / \mathrm{m}$. Group (A) of columns was immersed in $2 \% \mathrm{Na}_{2} \mathrm{SO}_{4}+1 \% \mathrm{CaCL}_{2}$, Group (B) of columns was immersed in $4 \% \mathrm{Na}_{2} \mathrm{SO}_{4}+2 \% \mathrm{CaCL}_{2}$. But, Group (C) was immersed in $6 \% \mathrm{Na}_{2} \mathrm{SO}_{4}+$ $3 \% \mathrm{CaCL}_{2}$ for a period of 7 months. Details of reinforcement and measured deformations are shown in Fig. 1.

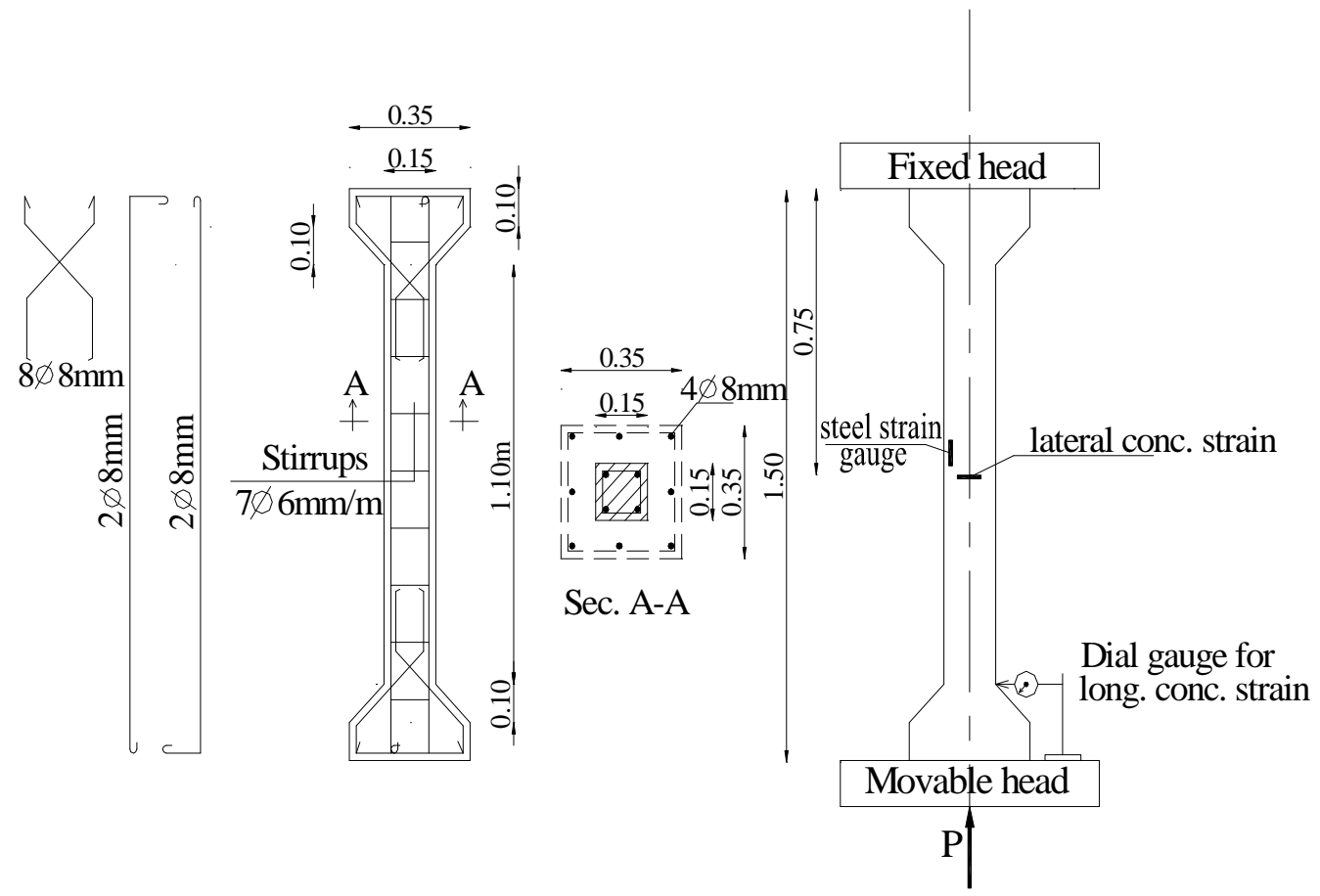

Fig. 1: Details of R.C. tested columns and method of measuring their deformations.

\section{3- MATERIALS}

\subsection{Technique Of Preparing And Producing The Suggested Admixtures}

The experimental technique for preparing and producing the suggested organic admixtures were carried out by the method explained in the our previous works [14]. The suggested organic admixtures type "SM-S", "CM-B" and "SM-O' are consist of 
the secondary products and alkali wastes $(\mathrm{pH}=9.5)$ of vegetable oil and cellulose paper industries, Calcium oxide "CaO", Superplasticizers "BVF", \& "PVS", and water.

The effect of composition and parameters of combination of different elements on the quality of the suggested admixtures was carried out by using the previous explained methods $[14,15]$. The composition and correlation of components of the proposed admixtures by weight from their solid particles are determined and shown in Table 1.

\subsection{Chemical Analysis Of Alkali Industrial Wastes}

Alkali wastes from cellulose paper industries consist of lime clay and clay from industrial sewage station. Chemical analysis of alkali wastes from cellulose paper industries (type lime clay and clay of industrial sewage station) was carried out and the results are shown in Tables 2, 3.

Table 1: Composition and correlation of components of the organic admixtures.

\begin{tabular}{|c|c|c|}
\hline $\begin{array}{c}\text { Type of } \\
\text { admixture }\end{array}$ & Components of the admixture & $\begin{array}{c}\text { Correlation of } \\
\text { components, } \% \text { by weight }\end{array}$ \\
\hline $\begin{array}{c}\text { "SM-O“" } \\
\text { (Suggested ) }\end{array}$ & $\begin{array}{l}\text { 1-Alkali wastes of vegetable oil } \\
\text { industries (liquidity solution } \mathrm{pH}=9.5 \text { ) } \\
\text { 2-Calcium oxide "CaO", and } \\
\text { 3-Water }\end{array}$ & $\begin{array}{c}8.00 \\
0.62 \\
91.38\end{array}$ \\
\hline $\begin{array}{c}\text { "SM-S" } \\
\text { (Suggested ) }\end{array}$ & $\begin{array}{l}\text { 1-Alkali wastes of vegetable oil } \\
\text { industries (liquidity solution } \mathrm{pH}=9.5 \text { ), } \\
\text { 2-calcium oxide "CaO", } \\
\text { 3- Superplasticizer "PVS “, and } \\
\text { 4-Water }\end{array}$ & $\begin{array}{c}8.00 \\
0.67 \\
1.87 \\
89.46\end{array}$ \\
\hline $\begin{array}{c}\text { “CM-B“" } \\
\text { (suggested) }\end{array}$ & $\begin{array}{l}\text { 1-Alkali wastes of cellulose paper } \\
\text { industries (liquidity solution } \mathrm{pH}=9 \text { ), } \\
\text { 2-Calcium oxide "CaO" , } \\
\text { 3-Superplasticizer "BVF" , and } \\
\text { 4-Water }\end{array}$ & $\begin{array}{c}8.00 \\
0.67 \\
1.76 \\
89.57\end{array}$ \\
\hline
\end{tabular}

Table 2: Chemical analysis of alkali wastes (type: Lime clay) from cellulose paper industries.

\begin{tabular}{|c|c|c|c|c|c|c|c|c|}
\hline Components & $\begin{array}{c}\text { Silica }+ \\
\text { non-soluble } \\
\text { materials }\end{array}$ & $\begin{array}{c}\text { Combined } \\
\text { Oxides }\end{array}$ & $\begin{array}{c}\text { Sodium } \\
\text { hydroxide } \\
\mathrm{Na}(\mathrm{OH})\end{array}$ & $\begin{array}{c}\text { Sodium } \\
\text { sulfide } \\
\mathrm{Na}_{2} \mathrm{~S}\end{array}$ & $\begin{array}{c}\text { Sodium } \\
\text { carbonate } \\
\mathrm{Na}_{2}\left(\mathrm{CO}_{3}\right)\end{array}$ & $\begin{array}{c}\text { Sodium } \\
\text { sulfate } \\
\mathrm{Na}_{2}\left(\mathrm{SO}_{4}\right)\end{array}$ & $\begin{array}{c}\text { Calcium } \\
\text { carbonate } \\
\mathrm{Ca}\left(\mathrm{CO}_{3}\right)\end{array}$ & Unknowns \\
\hline Correlation, \% & 7.27 & 1.05 & 0.481 & 0.039 & 0.848 & 0.243 & 89.982 & 0.087 \\
\hline
\end{tabular}

Table 3: Chemical analysis of alkali wastes (type: clay of industrial sewage station) from cellulose paper industries.

\begin{tabular}{|c|c|c|c|c|}
\hline Components & Organic Materials & Azot & Phosphates & Ashes \\
\hline Correlation, $\%$ & 91.252 & 2.1 & 0.389 & 6.259 \\
\hline
\end{tabular}




\subsection{Normal Strength Concrete}

Concrete mixes were used to produce normal strength concrete having 28-days cubic compressive strengths of $250-300 \mathrm{~kg} / \mathrm{cm}^{2}$. Optimum dose of each admixture, at which occurs maximum values of compressive strength was determined by the previous methods $[14,15]$. The influence of the value of optimum dose and type of each admixture on the compressive strength of concrete after $28 \& 210$-days hardening in fresh water are shown in Table 4. Ordinary Portland cement of specific gravity 3.2 was used (Assiut cement). Coarse aggregate used was $20 \mathrm{~mm}$ maximum nominal size and fineness modulus 7.12. Local natural sand of fineness modulus 2.35 was used as a fine aggregate.

Table 4: Details of concrete mixes and their compressive strengths " $\mathrm{Fc}$ " at optimum dose of the suggested admixtures (hardened in fresh water).

\begin{tabular}{|c|c|c|c|c|c|c|c|c|c|}
\hline \multirow{2}{*}{$\begin{array}{l}\text { Mix } \\
\text { No. }\end{array}$} & \multicolumn{3}{|c|}{$\begin{array}{c}\text { Mix components, } \\
\mathrm{Kg} / \mathrm{m}^{3}\end{array}$} & \multicolumn{2}{|c|}{ Suggested Admixtures } & \multirow[b]{2}{*}{$\mathrm{W} / \mathrm{C}$} & \multirow{2}{*}{$\begin{array}{l}\text { Slump, } \\
\mathrm{cm}\end{array}$} & \multicolumn{2}{|c|}{$\mathrm{Fc}, \mathrm{kg} / \mathrm{cm}^{2}$} \\
\hline & C & $S$ & G & Type & $\begin{array}{l}\text { Optimum dose, } \% \text { by } \\
\text { weight of cement }\end{array}$ & & & $\begin{array}{c}28 \\
\text { days }\end{array}$ & $\begin{array}{l}210 \\
\text { days }\end{array}$ \\
\hline 1 & 350 & 671 & 1283 & ----- & 0.00 & 0.44 & 5.5 & 276 & 288 \\
\hline 2 & 350 & 676 & 1292 & SM-O & 0.25 & 0.43 & 5.5 & 282 & 341 \\
\hline 3 & 350 & 679 & 1298 & $\overline{\mathrm{CM}-\mathrm{B}}$ & 0.25 & 0.42 & 5.5 & 321 & 347 \\
\hline 4 & 350 & 680 & 1300 & SM-S & 0.25 & 0.41 & 5.5 & 330 & 356 \\
\hline 5 & 350 & 688 & 1316 & DM2 & 0.25 & 0.38 & 5.5 & 420 & 427 \\
\hline
\end{tabular}

\subsection{Steel Reinforcement}

The steel bars used, as compression reinforcement of columns was a normal strength mild plain bar having diameter $8 \mathrm{~mm}$ (yield stress $2800 \mathrm{~kg} / \mathrm{cm}^{2}$, ultimate strength 4610 $\mathrm{kg} / \mathrm{cm}^{2} \& \%$ of elongation 19.8) and stirrups $6 \mathrm{~mm}$ diameter (yield stress $2670 \mathrm{~kg} / \mathrm{cm}^{2}$, ultimate strength $3670 \mathrm{~kg} / \mathrm{cm}^{2} \& \%$ of elongation 21.7 )

\subsection{External Sulfate And Chloride Solutions}

Three different concentrations of sodium sulfate " $\mathrm{Na}_{2} \mathrm{SO}_{4}$ " and calcium chloride " $\mathrm{CaCL}_{2}$ " were used as external sulfate and chloride attack.

\subsection{Test Procedure}

The testing machine (EMS 500-tons) was used. Each column was loaded axially and gradually keeping the rate of loading constant. The columns were tested after 7 months immerssing in sulfate and chloride solutions under static axial loading. The axial load was applied gradually with an increment of 2 tons up to cracking and failure. After each increment, reading of strain gauges, dial gauges and crack propagation for each group of tested columns was recorded.

\section{4- RESULTS AND DISCUSSIONS}

Test results of the fifteen R.C. tested columns (three groups A, B \& C), are presented in Tables 5, 6 \& 7. The tables also include the predicted ultimate capacities of the tested columns using the method of Egyptian code of practice. 


\subsection{Cracks And Mode Of Failure Of The Tested R.C Columns}

Cracks, mode of failure and properties of the failure zone of all groups of tested columns after 7 months hardening in sulfate and chloride solutions are shown in Table 5 and photos 1, 2, \& 3 in Fig. 2.

\subsubsection{Cracks and mode of failure of R.C. tested columns (Group A)}

Cracks initiated and failure occurred with a buckling of steel reinforcement at the ultimate load as a shear failure accompanied by crushing with high explosive sound at the middle third region in case of control tested column without admixtures. But, they were initiated and failure occurred with a small buckling of steel reinforcement at the ultimate load as a shear failure accompanied by crushing with low explosive sound at the lower one third region in case of columns modified with admixtures containing alkali wastes of oil industries (type SM-S \&SM-O) and plasticizing admixture (DM2).

Table 5: Properties of the failure zone of all tested columns after 7 months hardening in sulfate and chloride solutions.

\begin{tabular}{|c|c|c|c|c|c|c|c|}
\hline $\begin{array}{c}\text { Group } \\
\text { No. }\end{array}$ & $\begin{array}{l}\text { No. } \\
\text { of } \\
\text { columns }\end{array}$ & $\begin{array}{c}\text { Type of } \\
\text { Admixture, } \\
\text { dose, } \%\end{array}$ & $\begin{array}{l}\text { Conc.of } \\
\text { salt } \\
\text { solutions }\end{array}$ & $\begin{array}{c}\text { Height of } \\
\text { lower level } \\
\text { of failure } \\
\text { zone, cm }\end{array}$ & $\begin{array}{l}\text { Height } \\
\text { of failure } \\
\text { zone, cm }\end{array}$ & $\begin{array}{l}\text { Height of } \\
\text { upper level } \\
\text { of failure } \\
\text { zone, } \mathrm{cm}\end{array}$ & $\begin{array}{c}\text { Mode of failure, angle } \\
\text { of shear failure, } \\
\text { degrees }\end{array}$ \\
\hline \multirow{5}{*}{ A } & $\mathrm{C}_{1-1}$ & Control & \multirow{5}{*}{$\begin{array}{c}2 \% \\
\mathrm{Na}_{2} \mathrm{SO}_{4} \\
+1 \% \\
\mathrm{CaCl}_{2}\end{array}$} & 30 & 35 & 65 & Shear failure, $\theta=66$ \\
\hline & $\mathrm{C}_{2-1}$ & $\mathrm{DM} 2, .25 \%$ & & 15 & 35 & 50 & Shear failure, $\theta=66$ \\
\hline & $\mathrm{C}_{3-1}$ & SM-S,.25\% & & 12 & 22 & 34 & Shear failure, $\theta=56$ \\
\hline & $\mathrm{C}_{4-1}$ & CM-B,.25\% & & 113 & 25 & 138 & Shear failure, $\theta=59$ \\
\hline & $\mathrm{C}_{5-1}$ & SM-O,.25\% & & 15 & 35 & 50 & Shear failure, $\theta=66$ \\
\hline \multirow{5}{*}{ B } & $\mathrm{C}_{1-2}$ & Control & \multirow{5}{*}{$\begin{array}{c}4 \% \\
\mathrm{Na} 2 \mathrm{SO} 4 \\
+2 \% \\
\mathrm{CaCl} 2\end{array}$} & 107 & 33 & 140 & Shear failure, $\theta=65$ \\
\hline & $\mathrm{C}_{2-2}$ & $\mathrm{DM} 2, .25 \%$ & & 33 & 30 & 63 & Shear failure, $\theta=63$ \\
\hline & $\mathrm{C}_{3-2}$ & SM-S,.25\% & & 99 & 26 & 125 & Shear failure, $\theta=60$ \\
\hline & $\mathrm{C}_{4-2}$ & CM-B,.25\% & & 115 & 25 & 140 & Shear failure, $\theta=59$ \\
\hline & $\mathrm{C}_{5-2}$ & SM-O,.25\% & & 5 & 24 & 29 & Shear failure, $\theta=58$ \\
\hline \multirow{5}{*}{$\mathrm{C}$} & $\mathrm{C}_{1-3}$ & \begin{tabular}{|l} 
Control \\
\end{tabular} & \multirow{5}{*}{$\begin{array}{c}6 \% \\
\mathrm{Na} 2 \mathrm{SO} 4 \\
+3 \% \\
\mathrm{CaCl} 2\end{array}$} & 102 & 31 & 133 & Shear failure, $\theta=64$ \\
\hline & $\mathrm{C}_{2-3}$ & DM2,. $25 \%$ & & 12 & 31 & 43 & Shear failure, $\theta=64$ \\
\hline & $\mathrm{C}_{3-3}$ & SM-S,.25\% & & 120 & 20 & 140 & Shear failure, $\theta=53$ \\
\hline & $\mathrm{C}_{4-3}$ & $\mathrm{CM}-\mathrm{B}, .25 \%$ & & 65 & 27 & 92 & Shear failure, $\theta=61$ \\
\hline & $\mathrm{C}_{5-3}$ & SM-O,.25\% & & 107 & 31 & 138 & Shear failure, $\theta=64$ \\
\hline
\end{tabular}

And, at the upper one-third region in case of columns modified with admixtures containing alkali wastes of cellulose paper industries (type CM-B). Levels and height of the failure zone for each type of columns are shown in Table 5 and photo 1. From which it is clear that, the suggested admixtures (type SM-S \& CM-B ) reduce the height of the failure zone by about $37 \& 29 \%$ respectively compared to the control column. In the same time, the admixture (CM-B) and control admixture (DM2) has nearly the same lower level of failure zone of control column but they reduce the sound of crushing. 


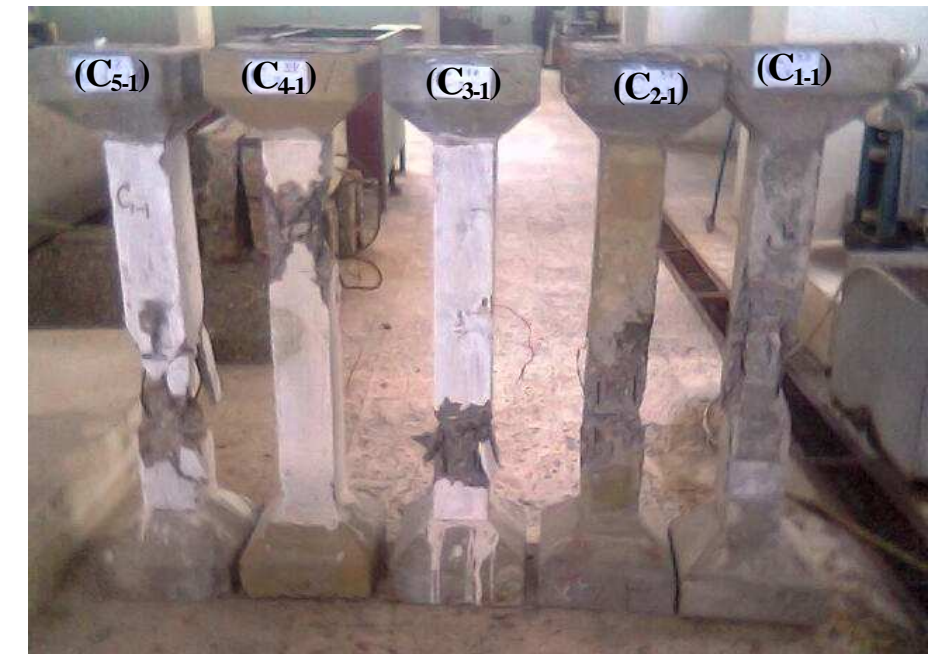

Photo 1: Cracks and mode of failure of R.C. tested columns (Group A)

$\left(\mathrm{C}_{1-1}\right)$ : Control column $\left(\mathrm{C}_{2-1}\right)$ : with admixture DM2 $\left(\mathrm{C}_{3-1}\right)$ : with admixture SM-S $\left(\mathrm{C}_{4-1}\right)$ : with admixture CM-B $\left(\mathrm{C}_{5-1}\right)$ : with admixture SM-O

Photo 2: Cracks and mode of failure of R.C. tested columns (Group B)

$\left(\mathrm{C}_{1-2}\right)$ : Control column $\left(\mathrm{C}_{2-2}\right)$ : with admixture DM2 $\left(\mathrm{C}_{3-2}\right)$ : with admixture SM-S $\left(\mathrm{C}_{4-2}\right)$ : with admixture $\mathrm{CM}-\mathrm{B}$ $\left(\mathrm{C}_{5-2}\right)$ : with admixture SM-O

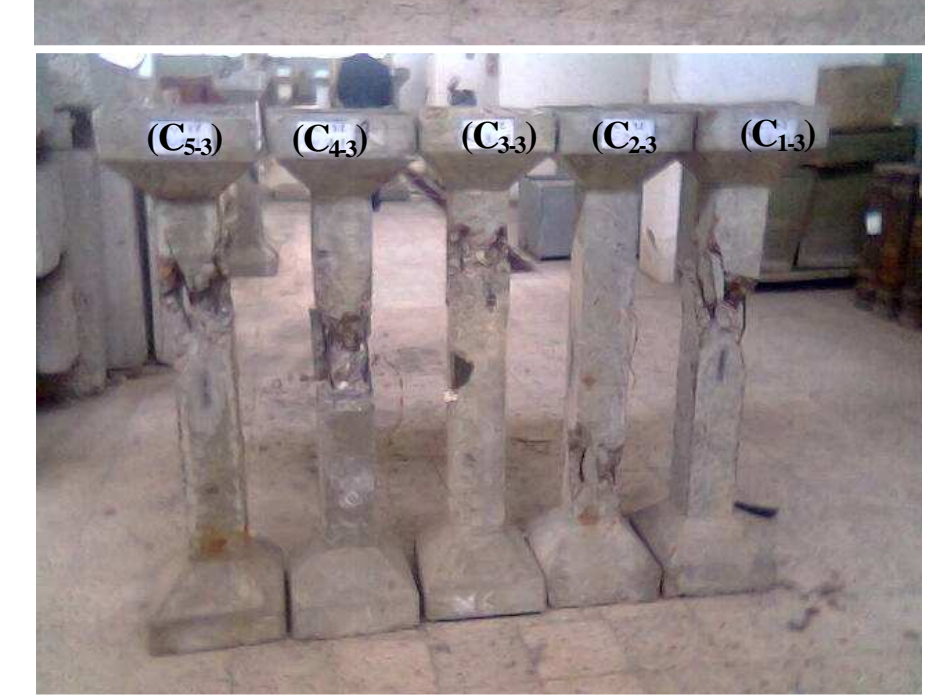

Photo 3: Cracks and mode of failure of R.C. tested columns (Group C)

$\left(\mathrm{C}_{1-3}\right)$ : Control column $\left(\mathrm{C}_{2-3}\right)$ : with admixture DM2 $\left(\mathrm{C}_{3-3}\right)$ : with admixture SM-S $\left(\mathrm{C}_{4-3}\right)$ : with admixture CM-B $\left(\mathrm{C}_{5-3}\right)$ : with admixture SM-O

Fig. 2: Cracks and modes of failure for all groups of R.C. tested columns. 


\subsubsection{Cracks and mode of failure of R.C. tested columns (Group B)}

Cracks initiated and failure occurred with a buckling of steel reinforcement at the ultimate load as a shear failure accompanied by crushing with high explosive sound at the upper one third region in cases of control tested column without admixtures and column modified with admixture (CM-B), which containing alkali wastes of cellulose paper industries. But, they were initiated and failure occurred with a small buckling of steel reinforcement at the ultimate load as a shear failure accompanied by crushing with low explosive sound at the middle third region in case of columns modified with admixture containing alkali wastes of oil industries (type SM-S) and plasticizing admixture (DM2). And, at the lower one-third region in case of columns modified with admixture (type SM-O).

Levels and height of the failure zone for each type of columns are shown in Table 5. From which it is clear that, the suggested admixtures (type SM-S, CM-B \& SM-O) reduce the height of the failure zone by about $22,25 \& 28 \%$ respectively compared to the control column. In the same time, the control admixture (DM2) reduces failure zone height by about $9 \%$ only. The admixtures containing alkali wastes of oil industries (SM-S \& SM-O ) decrease the lower level of the failure zone by about 8 \& $95 \%$ respectively. But, admixture containing alkali wastes of cellulose paper industries (type CM-B) has nearly the same lower level of failure zone of control column.

\subsubsection{Cracks and mode of failure of R.C. tested columns (Group C)}

Cracks initiated and failure occurred with a buckling of steel reinforcement at the ultimate load as a shear failure accompained by crushing with high explosive sound at the upper one third region in cases of control tested column without admixtures and columns modified with the suggested admixtures (SM-S \& SM-O), which containing alkali wastes of oil industries, and in the middle third region for column with admixture (CM-B). But, they were initiated and failure occurred with a small buckling of steel reinforcement at the ultimate load as a shear failure accompanied by crushing with high explosive sound at the lower one third region in case of columns modified with control plasticizing admixture (DM2).

Levels and height of the failure zone for each type of columns are shown in Table 5. From which it is clear that, the suggested admixtures (type SM-S\& CM-B) reduce the height of the failure zone by about $35 \& 21 \%$ respectively compared to the control column. But, admixture containing alkali wastes of oil industries (type SM-O) and control admixture (DM2) has nearly the same lower level of failure zone of control column. It is necessary to notice that, the organic admixture (CM-B) containing alkali wastes of cellulose paper industries has nearly no effect on changing the failure zone region. It has the ability of keeping failure site at the upper or the middle third region for all groups of tested columns, which increase the degree of warning against failure compared to the control admixture (DM2). This may be explained by its effect on improvement the micro porous structure of the hardened concrete in aggressive conditions.

The positive influence of the suggested admixtures especially SM-S \& CM-B on improvement properties of the failure zone, (decrease of the depth $\&$ increase of the height of lower and upper level of the failure zone) may be explained by the 
following: the addition of plasticizers with a small doses to the liquidity alkali industrial wastes help in the solubility of organic elements with water and produce homogeneous liquidity organic admixtures. These changes regulate the microstructure formation of cement paste and produce more dense, homogeneous and impermeable concrete. Consequently, the bond forces between steel and concrete increased, the internal cracks decreased and the properties of the failure zone improved.

\subsection{Corrosion Damage Of The Tested R.C Columns}

It is necessary to notice that, after 7 months hardening of column specimens in sulfate and chloride solutions, the embedded steel bars of the control tested columns have a clear corrosion damage and its rate increases with high concentrations of sulfate and chloride solutions. But, in case of columns modified with admixtures (SM-S \&SM-O), which contain alkali wastes from oil industries, the embedded steel bars have a little corrosion damage. In case of columns modified with admixture (CM-B), which contain alkali wastes from cellulose paper industries, the embedded steel bars have a neglected corrosion damage for all different concentrations of salt solutions.

\subsection{Ultimate Loads}

Table 6 shows the experimental and theoretical ultimate loads of all groups of R.C. tested columns, after 7 months hardening in sulfate and chloride solutions, under static load.

Table 6: Experimental and theoretical ultimate loads for all tested columns after 7 months hardening in sulfate and chloride solutions.

\begin{tabular}{|c|c|c|c|c|c|c|c|}
\hline \multirow{2}{*}{$\begin{array}{c}\text { Group } \\
\text { No. }\end{array}$} & \multirow{2}{*}{$\begin{array}{c}\text { No.of } \\
\text { Columns }\end{array}$} & \multirow{2}{*}{$\begin{array}{c}\text { Type of } \\
\text { Admixture, } \\
\text { dose, } \%\end{array}$} & \multirow{2}{*}{$\mathrm{W} / \mathrm{C}$} & \multirow{2}{*}{$\begin{array}{l}\text { Conc.of } \\
\text { salt } \\
\text { solutions }\end{array}$} & \multirow{2}{*}{$\begin{array}{l}\mathrm{Fc}_{210} \\
\mathrm{Kg} / \mathrm{cm}^{2}\end{array}$} & \multicolumn{2}{|c|}{ Ultimate load, $\mathrm{Pu}$, tons } \\
\hline & & & & & & Pu exp. & Pu th. \\
\hline \multirow{5}{*}{ A } & $\mathrm{C}_{1-1}$ & Control & 0.44 & \multirow{5}{*}{$\begin{array}{c}2 \% \\
\text { " } \mathrm{Na}_{2} \mathrm{SO}_{4} \\
" \\
+1 \% \\
\text { " } \mathrm{CaCl}_{2} "\end{array}$} & 275.0 & 45 & 47.1 \\
\hline & $\mathrm{C}_{2-1}$ & $\mathrm{DM} 2, .25 \%$ & 0.38 & & 364.7 & 58 & 60.6 \\
\hline & $\mathrm{C}_{3-1}$ & SM-S,.25\% & 0.41 & & 371.6 & 57 & 61.6 \\
\hline & $\mathrm{C}_{4-1}$ & CM-B,.25\% & 0.42 & & 381.2 & 61 & 63.0 \\
\hline & $\mathrm{C}_{5-1}$ & SM-O,.25\% & 0.43 & & 353.6 & 38 & 58.9 \\
\hline \multirow{5}{*}{ B } & $\mathrm{C}_{1-2}$ & Control & 0.44 & \multirow{5}{*}{$\begin{array}{c}4 \% \\
\text { " } \mathrm{Na}_{2} \mathrm{SO}_{4} \\
" \\
+2 \% \\
\text { " } \mathrm{CaCl}_{2} \text { " }\end{array}$} & 263.3 & 42 & 44.6 \\
\hline & $\mathrm{C}_{2-2}$ & $\mathrm{DM} 2, .25 \%$ & 0.38 & & 358.7 & 56 & 59.7 \\
\hline & $\mathrm{C}_{3-2}$ & SM-S,.25\% & 0.41 & & 400.4 & 59 & 60.4 \\
\hline & $\mathrm{C}_{4-2}$ & CM-B,.25\% & 0.42 & & 393.3 & 66 & 59.3 \\
\hline & $\mathrm{C}_{5-2}$ & SM-O,.25\% & 0.43 & & 355.3 & 42 & 59.1 \\
\hline \multirow{5}{*}{$\mathrm{C}$} & $\mathrm{C}_{1-3}$ & Control & 0.44 & \multirow{5}{*}{$\begin{array}{c}6 \% \\
\text { " } \mathrm{Na}_{2} \mathrm{SO}_{4} \\
" \\
+3 \% \\
\text { " } \mathrm{CaCl}_{2} "\end{array}$} & 258.6 & 39 & 42.3 \\
\hline & $\mathrm{C}_{2-3}$ & $\mathrm{DM} 2, .25 \%$ & 0.38 & & 338.1 & 54 & 56.6 \\
\hline & $\mathrm{C}_{3-3}$ & SM-S,.25\% & 0.41 & & 381.6 & 59 & 63.1 \\
\hline & $\mathrm{C}_{4-3}$ & CM-B,.25\% & 0.42 & & 353.3 & 55 & 58.8 \\
\hline & $\mathrm{C}_{5-3}$ & SM-O,.25\% & 0.43 & & 355.8 & 45 & 59.1 \\
\hline
\end{tabular}




\subsubsection{Ultimate loads of R.C tested columns (Group A)}

For group (A) of tested columns, which were hardened in $2 \% \mathrm{Na}_{2} \mathrm{SO}_{4}+1 \% \mathrm{CaCL}_{2}$ until 7 months, the suggested admixtures (type SM-S \& CM-B) have a good influence on increasing their experimental ultimate loads compared to the control tested column without admixtures. They increased ultimate load of this group of columns under axial static load by about $30 \& 39 \%$ respectively compared to the control columns. But, the admixture (SM-O) decreased their ultimate load by about $14 \%$ compared to the reference column. These admixtures, especially CM-B, also have a good influence on increasing ultimate loads by about 5\% over than that with the control plasticizing admixture (DM2).

\subsubsection{Ultimate loads of R.C tested columns (Group B)}

For group (B) of tested columns, which were hardened in $4 \% \mathrm{Na}_{2} \mathrm{SO}_{4}+2 \% \mathrm{CaCL}_{2}$ until 7 months, the suggested admixtures (type SM-S \& CM-B) also have a good influence on increasing their ultimate loads compared to the control tested column without admixtures. They increased ultimate and working load of this group of columns under axial static load by about $40 \& 57 \%$ respectively compared to the control column. But, the columns modified with admixture (SM-O) have the same value of ultimate load of the reference column. These admixtures, especially SM-S\& CM-B, also have a good influence on increasing ultimate loads by about 5\% \& $18 \%$ respectively over than that with the control plasticizing admixture (DM2).

It is necessary to notice that, the activity of admixture type (SM-O), which fabricated only from alkali wastes of oil industries plus calcium oxide, on increasing ultimate loads was increased by increasing the concentration of sulfate and chloride solutions from $3 \%$ to $9 \%$. So, the ultimate load of this group of columns modified with this economic organic admixture had the same value of the control column. But, the control R.C. column and that modified with the control plasticizing admixture (DM2) showed a decrease in their ultimate load by about $7 \& 5 \%$ by increasing concentration of the suggested salt solutions from 3 to $9 \%$.

\subsubsection{Ultimate loads of R.C tested columns (Group C)}

For group (C) of tested columns, which were hardened in $6 \% \mathrm{Na}_{2} \mathrm{SO}_{4}+3 \% \mathrm{CaCL}_{2}$ until 7 months, the columns modified with the suggested admixtures (type SM-S, CM-B\& SM-O) showed a large increase in their ultimate loads by about $51,41, \&$ $15 \%$ compared to the control tested column without admixtures. These admixtures, especially SM-S\& CM-B, also have a good influence on increasing ultimate loads by about $9 \%$ \& $2 \%$ respectively over than that with the control plasticizing admixture (DM2). Obviously, the activity of economic admixture type (SM-O), which fabricated only from alkali wastes of oil industries plus calcium oxide, on increasing ultimate loads was increased also by increasing the concentration of sulfate and chloride solutions from $3 \%$ to $9 \%$. So, the ultimate load of this group of columns modified with this economic organic admixture increased by about $18 \%$ than that value of the control column ( as shown in Fig. 3).

It is necessary to notice that, the increase of concentration of sulfate and chloride solutions from 3 to $9 \%$ had a neglected influence on reducing ultimate capacity of R.C. columns, after 7 months hardening in these conditions, modified with organic 
admixtures type SM-S \& CM-B (as shown in Fig. 3). But, the increase of concentration of sulfate and chloride solutions from 3 to $9 \%$ increased the reduction of ultimate loads of control columns without admixtures and with the control plasticizing admixtures (DM2) by about $14 \%$ \& $7 \%$, respectively.
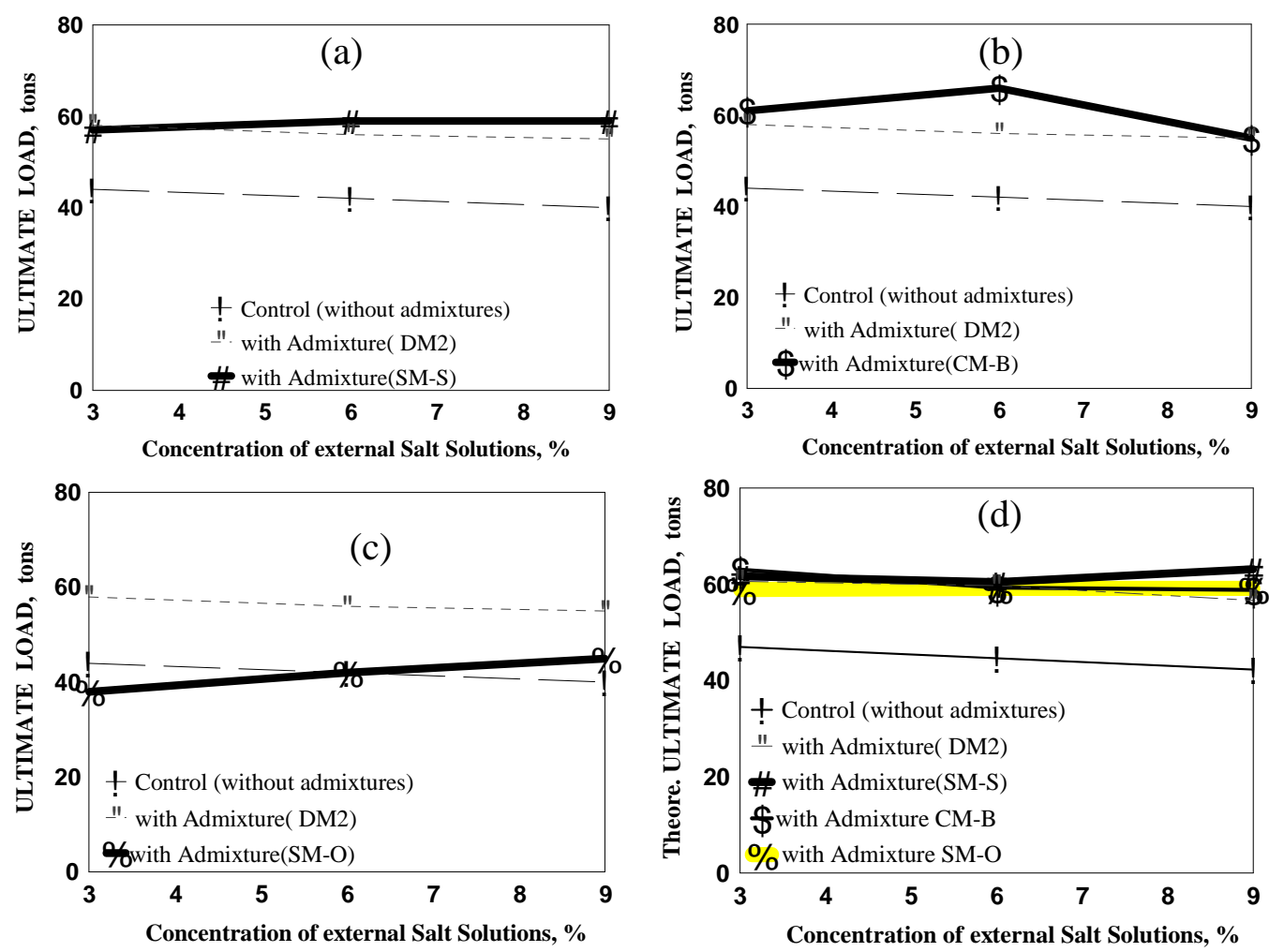

Fig.3: Ultimate loads of R.C. tested columns versus concentration of sulfate and Chloride solution as affected by each type of organic suggested admixtures.
a) Columns modified with admixture (SM-S) compared to control columns
b) Columns modified with admixture (CM-B) compared to control columns
c) Columns modified with admixture (SM-O) compared to control columns
d) Theoretical ultimate loads versus concentration of external salt solutions

So, the suggested admixtures, containing alkali wastes from oil and cellulose paper industries showed a good and clear effect on increasing ultimate capacity of R.C. columns hardened in different concentrations of sulfate and chloride solutions compared to the control tested columns. This may be explained by the following: these admixtures have the ability of forming organic layers around cement minerals, which keeping amount of them $\left(\mathrm{C}_{2} \mathrm{~S}+\mathrm{C}_{3} \mathrm{~S}\right)$ without hydration for a period of time. After a period of hardening in sulfate solutions, these organic layers destroyed and the nonhydrated cement minerals began to hydrate in the presence of water. So, additional reactions occurred and amount of crystalline hydrated phase (type calcium silicate hydrate $\mathrm{C}-\mathrm{S}-\mathrm{H}$ ) was produced and filled the internal pores in the concrete specimens. 
Consequently, regulation of microstructure formation occurred, denser and homogeneous concrete has produced. Therefore, concrete ultimate and working capacity improved in these aggressive conditions.

\subsection{Calculation Of The Maximum Ultimate Capacity And Actual Ultimate Strength Of R.C. Tested Columns}

The theoretical ultimate capacity $\left(\mathrm{Pu}_{\mathrm{th}}\right)$ and actual ultimate strength $\left(\mathrm{Fc}_{\mathrm{ul}}\right)$ of each type of R.C. tested columns with and without admixtures, which hardened in the suggested aggressive conditions until 7 months, were calculated according to the Egyptian code of practice and results are shown in Table 6. From Egyptian code of practice, the maximum theoretical ultimate capacity $\left(\mathrm{Pu}_{\mathrm{th}}\right.$. $)$ was calculated from the following equation:

$$
\mathrm{P}_{\mathrm{ul}} \text {.th. }=0.67 \mathrm{f}_{\mathrm{cu}} \times \mathrm{A}_{\mathrm{c}}+\mathrm{A}_{\mathrm{s}} \times \mathrm{F}_{\mathrm{y}}
$$

Where: $\mathrm{f}_{\mathrm{cu}}=$ cubic concrete compressive strength, $\mathrm{A}_{\mathrm{c}}=$ cross sectional area of each column, $\mathrm{A}_{\mathrm{s}}=$ area of steel reinforcement, $\mathrm{F}_{\mathrm{y}}=$ steel yield stress. Also, the actual ultimate strength of concrete $\left(\mathrm{Fc}_{\mathrm{ul}}\right)$ for each column was calculated from the following equation:

$$
P_{\text {ul }} \text { exp. }=f_{\text {cul }} \times A_{c}+0.44 A_{s} \times F_{y}
$$

Where: $P_{\mathrm{ul}}$.exp.= experimental ultimate load of each tested column.

The comparison between the predicted ultimate capacity of each column and that obtained experimentally was determined and shown in Table 6. The comparison shows that, there is a difference between the calculated values and the experimental values of the working capacity.

\subsubsection{Group (A) of tested columns}

The experimental values of ultimate capacity of tested columns, hardened in $2 \% \mathrm{Na}_{2} \mathrm{SO}_{4}+1 \% \mathrm{CaCL}_{2}$ is smaller than that calculated by Egyptian code by about 5 , $7,3, \& 35 \%$ for columns modified with suggested admixtures (DM2, SM-S, CM-B \& SM-O) respectively. But, for control tested columns without admixture, the experimental ultimate capacity is smaller than that predicted by about $5 \%$. But, the actual ultimate strength for column specimens modified with admixtures (DM2SM-S \& CM-B) increased respectively by about 30, $28 \& 38 \%$ compared to the control column. But, column modified with admixture (SM-O) showed a decrease of its ultimate strength of about $16 \%$ than the control (as shown in Table 6 \& Fig 4).

\subsubsection{Group (B) of tested columns}

The experimental values of ultimate capacity of tested columns, hardened in $4 \%$ $\mathrm{Na}_{2} \mathrm{SO}_{4}+2 \% \mathrm{CaCL}_{2}$ is smaller than that calculated by Egyptian code by about 7, 2, $\& 29 \%$ for columns modified with suggested admixtures (DM2, SM-S\& SM-O) respectively and increased by about $11 \%$ with admixture (CM-B). But, for control tested column without admixture, the experimental ultimate capacity is smaller than that predicted by about $6 \%$. But, the actual ultimate strength for column specimens modified with admixtures (DM2-SM-S\&CM-B) increased respectively by about 36 , $43 \& 61 \%$ compared to the control column. But, column modified with admixture (SM-O) showed the same value of the ultimate strength of the control column (as shown in ( Table 6 \& Fig 4). 

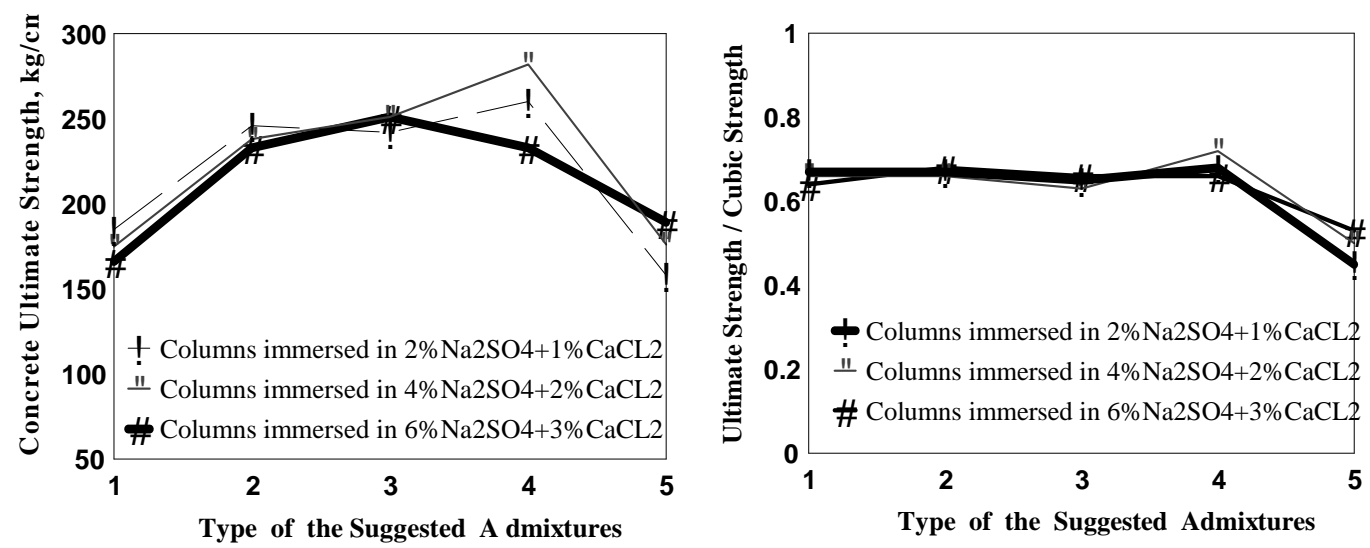

Fig. 4: Actual ultimate strength of different groups of R.C. tested columns as affected by each type of organic suggested admixtures.

1) Control columns without admixtures $\left(\mathrm{C}_{1-1}, \mathrm{C}_{1-2} \& \mathrm{C}_{1-3}\right)$,

2) Columns with control admixture DM2, 0.25\%(C2-1, C2-2 \& C2-3)

3) Columns with admixture SM-S, 0.25\%(C3-1, C3-2 \& C3-3),

4) Columns with admixture CM-B, $0.25 \%(\mathrm{C} 4-1, \mathrm{C} 4-2$ \& $\mathrm{C} 4-3)$,

5) Columns with admixture SM-O, 0.25\%(C5-1, C5-2 \& C5-3)

\subsubsection{Group (C) of tested columns}

The experimental values of ultimate capacity of tested columns, hardened in $6 \%$ $\mathrm{Na}_{2} \mathrm{SO}_{4}+3 \% \mathrm{CaCL}_{2}$ is smaller than that calculated by Egyptian code by about 5, 7, 6 , \& $24 \%$ for columns modified with suggested admixtures (DM2, SM-S, CM-B \& SM-O), respectively. But, for control tested column without admixture, the experimental ultimate capacity is smaller than that predicted by about $8 \%$. But, the actual ultimate strength for column specimens modified with admixtures (DM2, SM-S, CM-B \& SM-O) increased respectively by about 44, 55, $44 \& 17 \%$ compared to the control column.

It is necessary to notice that, the ultimate strength of R.C. columns containing admixture (SM-O) increased with the increase of sulfate and chloride solutions. But, this concentration has a very small effect on the ultimate strength of columns containing (SM-S \&CM-B) and it has a clear effect on reducing ultimate strength of control columns.

The difference between experimental and theoretical values of ultimate capacity of tested columns, hardened in different sulfate and chloride solutions is explained by the effect of high values of concrete compressive stresses which increase the actual ultimate strength and consequently the theoretical value. Also, this difference may be due to the first bond failure between steel and concrete before the final shear failure of the column. The positive influence of the suggested organic admixtures on improvement the experimental capacities of tested columns compared to the control columns is explained by their positive effect on increasing concrete compressive strength of tested columns hardened in these aggressive conditions. 


\subsection{Measured Deformations}

Generally, using organic admixtures with limited doses in the technology of concrete increases its compressive and durability in aggressive conditions and hense decreases its measured deformations $[14,15]$. This is also noticed for the R.C. columns made from normal strength concrete $\left(250-350 \mathrm{~kg} / \mathrm{cm}^{2}\right)$ with alkali industrial wastes, which were tested in this program. Axial applied load versus longitudinal and lateral deformation curves for all tested columns with and without admixtures are shown in Fig. 5.

\subsubsection{Ultimate Longitudinal concrete strains ( $€ \mathrm{C}$ I. )}

Table 7 and Fig. 6a show the influence of the suggested admixtures on the ultimate longitudinal concrete strain, which calculated at $85 \%$ from failure load, of different groups of R.C. tested columns. Obviously, the ultimate longitudinal concrete strain of group (A) of tested columns containing organic admixtures (SM-S, CM-B \&SM-O) decreased respectively by about $67,73 \& 67 \%$ compared with the control column. The best results occur with admixture containing alkali wastes of cellulose paper industries (CM-B). In the same time, column modified with the control admixture DM2 showed a decrease in its ultimate longitudinal concrete strain by about $67 \%$ compared to the control ones.

The ultimate longitudinal concrete strain of group (B) of tested columns containing organic admixtures (SM-S, CM-B \&SM-O) decreased respectively by about 53, 31 \& $20 \%$ compared to the control column. The good influence of this group of tested columns occurs with admixture containing alkali wastes of vegetable oil industries (SM-S). In the same time, column modified with the control admixture (DM2) showed a decrease in its ultimate longitudinal concrete strain by about $40 \%$ compared with the control ones.

The ultimate longitudinal concrete strain of group (C) of tested columns containing organic admixtures (SM-S, CM-B \&SM-O) decreased respectively by about 40, $24 \&$ $18 \%$ compared with the control column without admixtures. The good influence of this group of tested columns occurs with admixture containing alkali wastes of vegetable oil industries (SM-S). In the same time, column modified with the control admixture (DM2) showed a small decrease in its ultimate longitudinal concrete strain by about 3\% compared to the control ones. Obviously, the suggested organic admixtures showed a good influence on reducing ultimate longitudinal concrete strain of tested columns compared to the control plasticizing admixture (DM2). These admixtures decreased it respectively by about $37,19 \& 13 \%$ compared to the control admixture.

The clear and positive influence of the suggested admixtures on reducing ultimate longitudinal concrete strain is a result of their mechanism effect on regulating the microstructure of the hardened concrete and improvement its impermeability and mechanical properties. This leads to the decrease of large pores and internal cracks in the hardened concrete and consequently longitudinal and lateral deformations of concrete reduced. 

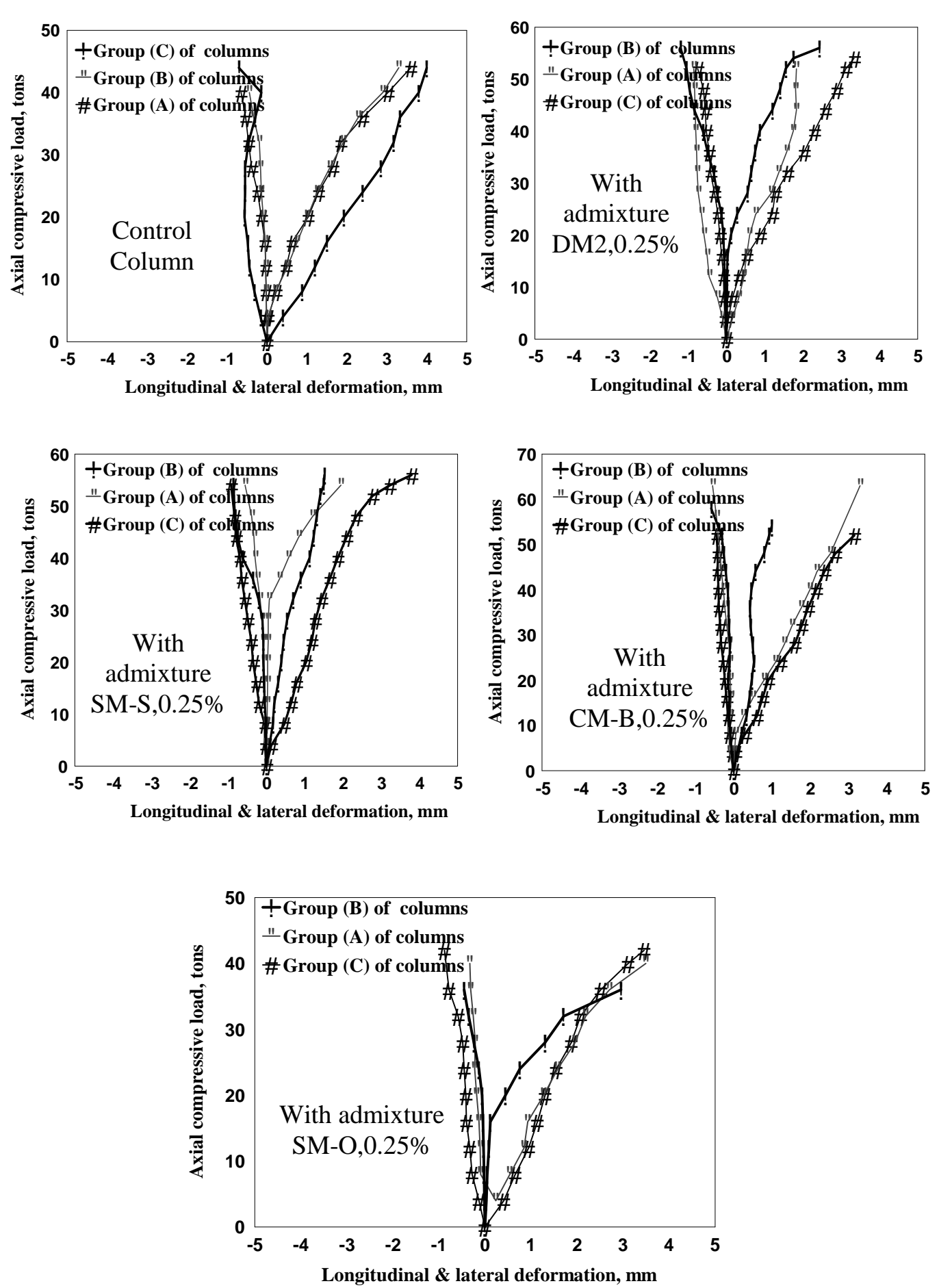

Fig. 5: Axial applied load versus longitudinal and lateral deformation curves of different groups of R.C. tested columns as affected by each type of organic suggested admixtures 
Table (7): Experimental results of ultimate strength and measured ultimate strains for all tested columns after 7 months hardening in sulfate and chloride solutions.

\begin{tabular}{|c|c|c|c|c|c|c|c|c|c|}
\hline $\begin{array}{c}\text { Group } \\
\text { No. }\end{array}$ & $\begin{array}{c}\text { No.of } \\
\text { columns }\end{array}$ & $\begin{array}{c}\text { Type of } \\
\text { Admixture, } \\
\text { dose, } \%\end{array}$ & $\begin{array}{c}\text { Conc. } \\
\text { of salt } \\
\text { solutions }\end{array}$ & $\begin{array}{l}\text { Ultimate } \\
\text { strength, } \\
\mathrm{Kg} / \mathrm{cm}^{2}\end{array}$ & $\begin{array}{l}\mathrm{Fc}_{\mathrm{ul}} / \\
\text { Fcu. }\end{array}$ & $\begin{array}{l}\text { Long. U1 } \\
\text { Con. Strai } \\
\text { Ec x } 10^{-4}\end{array}$ & $\mid \begin{array}{l}\text { Lat. U1 } \\
\text { Con. Straiı } \\
\text { Ge x } 10^{-4}\end{array}$ & $\begin{array}{c}\text { Long. U1 } \\
\text { Steel } \\
\text { Strain } \\
\text { Es x } 10^{-4}\end{array}$ & $\begin{array}{l}\text { Elastic } \\
\text { modulus } \\
\mathrm{Ec}, \mathrm{t} / \mathrm{cn}^{2}\end{array}$ \\
\hline \multirow{5}{*}{ A } & $C_{1-1}$ & \multirow{2}{*}{$\begin{array}{c}\text { Control } \\
\mathrm{DM} 2, .25 \% \\
\end{array}$} & \multirow{5}{*}{$\begin{array}{c}2 \% \\
\mathrm{Na}_{2} \mathrm{SO}_{4} \\
+1 \% \\
\mathrm{CaCl}_{2}\end{array}$} & 189 & 0.67 & 26.0 & 3.93 & 5.80 & 136.3 \\
\hline & $\mathrm{C}_{2-1}$ & & & 246 & 0.67 & 8.60 & 5.30 & 3.50 & 165.0 \\
\hline & $\mathrm{C}_{3-1}$ & SM-S,.25\% & & 242 & 0.65 & 8.57 & 5.40 & 7.50 & 217.0 \\
\hline & $\mathrm{C}_{4-1}$ & CM-B, $.25 \%$ & & 260 & 0.68 & 7.30 & 2.20 & 6.90 & 242.0 \\
\hline & $\mathrm{C}_{5-1}$ & SM-O,.25\% & & 158 & 0.45 & 8.60 & 2.13 & 6.60 & 218.0 \\
\hline \multirow{5}{*}{ B } & $C_{1-2}$ & \begin{tabular}{|c|} 
Control \\
\end{tabular} & \multirow{5}{*}{$\begin{array}{c}4 \% \\
\mathrm{Na} 2 \mathrm{SO} 4 \\
+2 \% \\
\mathrm{CaCl} 2\end{array}$} & 175 & 0.66 & 19.10 & 2.73 & 9.50 & 117.2 \\
\hline & $\mathrm{C}_{2-2}$ & $\mathrm{DM} 2, .25 \%$ & & 238 & 0.66 & 11.53 & 5.93 & 5.50 & 156.0 \\
\hline & $\mathrm{C}_{3-2}$ & SM-S,.25\% & & 251 & 0.63 & 9.00 & 2.80 & 7.70 & 201.0 \\
\hline & $\mathrm{C}_{4-2}$ & CM-B,.25\% & & 282 & 0.72 & 13.30 & 2.93 & 6.60 & 155.0 \\
\hline & $\mathrm{C}_{5-2}$ & SM-O,.25\% & & 176 & 0.50 & 15.40 & 3.46 & 4.40 & 133.2 \\
\hline \multirow{5}{*}{$\mathrm{C}$} & $C_{1-3}$ & \begin{tabular}{|l|} 
Control \\
\end{tabular} & \multirow{5}{*}{$\begin{array}{c}6 \% \\
\mathrm{Na} 2 \mathrm{SO} 4 \\
+3 \% \\
\mathrm{CaCl} 2\end{array}$} & 162 & 0.64 & 20.60 & 3.33 & 10.20 & 100.2 \\
\hline & $\mathrm{C}_{2-3}$ & $\mathrm{DM} 2, .25 \%$ & & 233 & 0.68 & 19.50 & 6.10 & 5.40 & 124.2 \\
\hline & $C_{3-3}$ & SM-S,.25\% & & 251 & 0.66 & 12.46 & 3.30 & 6.60 & 163.0 \\
\hline & $\mathrm{C}_{4-3}$ & CM-B, $.25 \%$ & & 233 & 0.66 & 15.80 & 2.73 & 2.73 & 131.0 \\
\hline & $C_{5-3}$ & SM-O,.25\% & & 189 & 0.53 & 17.00 & 4.26 & 3.29 & 123.0 \\
\hline
\end{tabular}

\subsubsection{Ultimate Lateral concrete strains (Eclat.)}

Table 7 and Fig. $\mathbf{6 b}$ show the influence of the suggested admixtures on the ultimate lateral concrete strains, which were calculated at $85 \%$ from failure load, of different groups of R.C. tested columns. Obviously, the ultimate laterial concrete strain of group (A) of tested columns containing organic admixtures (CM-B \&SM-O) decreased respectively by about $44 \& 46 \%$ compared to the control column without admixtures. The good influence occurs with admixture containing alkali wastes of oil industries (SM-O). In the same time, columns modified with the control admixture (DM2) and suggested admixture (SM-S) showed an increase in their ultimate laterial concrete strain by about $35 \& 37 \%$ respectively over than that of the control column. The ultimate lateral concrete strain of group (B) of tested columns containing organic admixtures (SM-S, CM-B \&SM-O) increased respectively by about $2.5,7 \& 26 \%$ compared to the control column. The good influence of this group of tested columns occurs with admixture containing alkali wastes of vegetable oil industries (SM-S). In the same time, column modified with the control admixture (DM2) showed a large increase in its ultimate lateral concrete strain of about $117 \%$ over than that of the control ones.

The ultimate lateral concrete strain of group (C) of tested columns containing organic admixtures (SM-S\& CM-B) decreased slowly by about $18 \%$ compared to the control column without admixtures. In the same time, column modified with the control admixture (DM2) and suggested admixture (SM-O) showed respectively an increase 
in their ultimate lateral concrete strain by about $83 \& 28 \%$ compared to the control ones. So, the suggested organic admixtures type (SM-S, CM-B) showed a clear and good influence on reducing lateral ultimate concrete strain of tested columns hardened in high concentrations of sulfate and chloride solutions until 7 months. But, the control admixture (DM2) and suggested type (SM-O) have a bad influence on improvement laterial concrete strain of this group of tested columns.

\subsubsection{Ultimate Longitudinal steel strains ( $\epsilon$ sl. )}

Table 7 and Fig. 6c show the influence of the suggested admixtures on the ultimate longitudinal steel strains, which were calculated at $85 \%$ from failure load, of different groups of R.C. tested columns.

For group (A) of tested columns, the columns containing organic admixtures (SM-S, CM-B \&SM-O) showed respectively an increase of their ultimate steel strain of about $29,19 \& 14 \%$ over than that of the control column. The good influence occurs with admixture containing alkali wastes of oil industries (SM-O). But, column modified with the control admixture (DM2) showed a decrease in its ultimate longitudinal steel strain of about $40 \%$ lower than that of the control ones.

For group (B) of tested columns, the columns containing organic admixtures (SM-S, CM-B \&SM-O) showed respectively a decrease of their ultimate steel strain of about $19,31 \& 54 \%$ lower than that of the control column. The good influence occurs with admixture containing alkali wastes of oil industries (type SM-O). Also, column modified with the control admixture (DM2) showed a decrease in its ultimate longitudinal steel strain of about $42 \%$ lower than that of the control ones. So, the suggested admixture containing alkali wastes of oil industries (type SM-O) showed a good influence than the control admixture (type DM2).

For group (C) of tested columns, the columns containing organic admixtures (SM-S, CM-B \&SM-O) showed respectively a clear decrease of their ultimate steel strain of about $36,73 \& 68 \%$ lower than that of the control column. The good influence occurs with admixture containing alkali wastes of cellulose paper and oil industries (type CM-B\&SM-O). Also, column modified with the control admixture (DM2) showed a decrease in its ultimate longitudinal steel strain of about $47 \%$ lower than that of the control ones. Therefore, it is clear that the effectiveness of the suggested admixture containing alkali wastes of oil and cellulose paper industries on reducing the ultimate steel strain of R.C. columns hardened in high concentrations of sulfate and chloride solutions until 7 months.

The clear and positive influence of the suggested admixtures on reducing ultimate longitudinal steel strain is a result of their mechanism effect on regulating the microstructure of the hardened concrete and improvement its impermeability and bond stresses between steel and concrete. This leads to the decrease of large pores and internal cracks of cement paste around embedded steel in the hardened concrete. Consequently, longitudinal deformations of embedded bars in the concrete reduced.

\subsubsection{Modulus of elasticity of concrete (Ec)}

Table 7 and Fig. 6d show the influence of the suggested admixtures on the elastic modulus of concrete, which was calculated as the stress divided by the strain at $30 \%$ from failure load, of different groups of R.C. tested columns. 
For group (A) of tested columns, the columns containing admixtures (DM2, SM-S \& CM-B) showed respectively a large increase of their concrete elastic modulus of about $30,28 \& 38 \%$ over than that of the control column. The good influence occurs with admixture containing alkali wastes of cellulose paper industries (CM-B). But, column modified with the suggested admixture (SM-O) showed a decrease of its concrete elastic modulus of about $16 \%$ compared to the control column.

a)

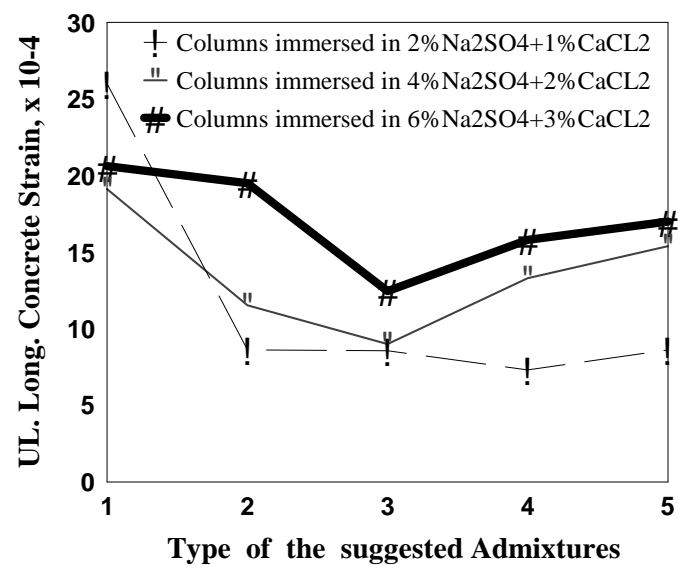

c)

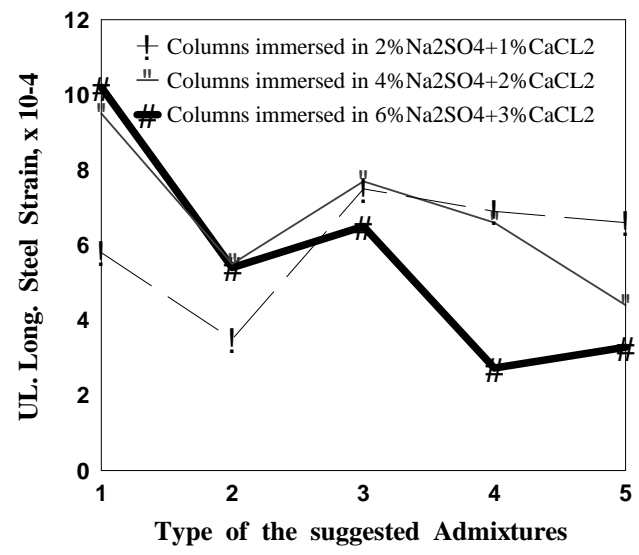

b) $\square$

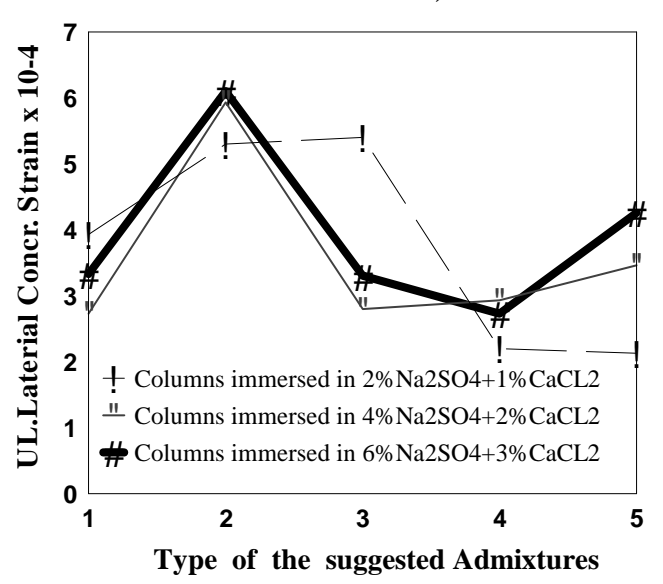

d)

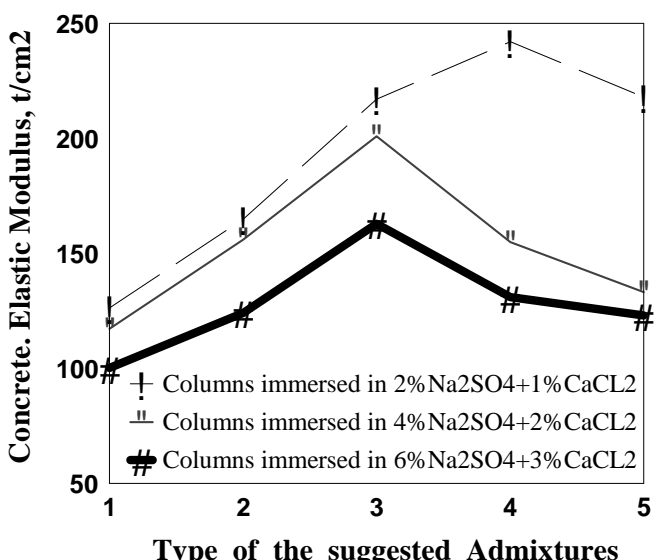

Fig. 6: Ultimate measured deformations of different groups of R.C. tested columns as affected by each type of organic suggested admixtures.

1) Control columns without admixtures $\left(\mathrm{C}_{1-1}, \mathrm{C}_{1-2} \& \mathrm{C}_{1-3}\right)$,

2) Columns with control admixture DM2, $0.25 \%\left(\mathrm{C}_{2-1}, \mathrm{C}_{2-2} \& \mathrm{C}_{2-3}\right)$

3) Columns with admixture $\mathrm{SM}-\mathrm{S}, 0.25 \%\left(\mathrm{C}_{3-1}, \mathrm{C}_{3-2} \& \mathrm{C}_{3-3}\right)$,

4) Columns with admixture CM-B, $0.25 \%\left(\mathrm{C}_{4-1}, \mathrm{C}_{4-2} \& \mathrm{C}_{4-3}\right)$,

5) Columns with admixture $\mathrm{SM}-\mathrm{O}, 0.25 \%\left(\mathrm{C}_{5-1}, \mathrm{C}_{5-2} \& \mathrm{C}_{5-3}\right)$ 
For group (B) of tested columns, the columns containing admixtures (DM2, SM-S \& CM-B) showed respectively a large increase of their concrete elastic modulus of about $36,43 \& 51 \%$ over than that of the control column. The good influence occurs with admixture containing alkali wastes of cellulose paper industries (CM-B). But, column modified with the suggested admixture (SM-O) has the same value of concrete elastic modulus for the control column.

For group (C) of tested columns, the columns containing admixtures (DM2, SM-S, CM-B \& SM-O)) showed respectively a large increase of their concrete elastic modulus of about $44,55,44 \& 17 \%$ over than that of the control column. The good influence occurs with admixture containing alkali wastes of oil and cellulose paper industries (SM-S \&CM-B).

The positive influence of the suggested organic admixtures on improvement the modulus of elasticity of tested columns compared to the control columns, which hardened in these aggressive conditions, is explained by their positive effect on increasing concrete compressive strength, ultimate loads and bond forces between filling materials of tested columns and decreasing their concrete longitudinal strain. Consequently, modulus of elasticity and stiffness of the R.C. columns increased.

\subsection{Energy Absorption, Toughness And Ductility Index For All Tested Columns}

Table 8 shows the influence of the suggested admixtures on the energy absorption, toughness and ductility index of different groups of R.C. tested columns after 7months hardening in sulfate and chloride solutions.

Table 8: Effect of different types of admixtures on the energy absorption and ductility index for all tested columns after 7 months hardening in sulfate and chloride solutions.

\begin{tabular}{|c|c|c|c|c|c|c|c|c|}
\hline $\begin{array}{l}\text { Grpoup } \\
\text { No. }\end{array}$ & $\begin{array}{c}\text { No.of } \\
\text { columns }\end{array}$ & $\begin{array}{l}\text { Type of } \\
\text { Admixture, } \\
\text { dose, } \%\end{array}$ & $\begin{array}{c}\text { Conc. } \\
\text { of salt } \\
\text { solutions }\end{array}$ & $\begin{array}{c}\text { Failure } \\
\text { load, ton }\end{array}$ & \begin{tabular}{|c} 
Long. Ul \\
Concrete \\
deformation, \\
$\mathrm{mm}$
\end{tabular} & $\begin{array}{c}\text { Energy } \\
\text { absorption, } \\
\text { ton.cm }\end{array}$ & $\begin{array}{c}\text { Toughness } \\
\text { t.cm/ } / \mathrm{cm}^{3} \\
X 10^{-4}\end{array}$ & $\begin{array}{c}\text { Toughness } \\
\text { or } \\
\text { ductility } \\
\text { index }\end{array}$ \\
\hline \multirow{5}{*}{ B } & $\mathrm{C}_{1-2}$ & Control & \multirow{5}{*}{$\begin{array}{c}4 \% \\
\mathrm{Na}_{2} \mathrm{SO}_{4} \\
+2 \% \\
\mathrm{CaCl}_{2}\end{array}$} & 42 & 3.60 & 10.13 & 3.00 & 1.00 \\
\hline & $\mathrm{C}_{2-2}$ & $\mathrm{DM} 2, .25 \%$ & & 56 & 2.43 & 9.12 & 2.70 & 0.90 \\
\hline & $\mathrm{C}_{3-2}$ & SM-S,.25\% & & 59 & 3.52 & 13.91 & 4.12 & 1.37 \\
\hline & $\mathrm{C}_{4-2}$ & CM-B,.25\% & & 66 & 3.31 & 14.64 & 4.33 & 1.45 \\
\hline & $\mathrm{C}_{5-2}$ & SM-O,.25\% & & 42 & 3.46 & 9.73 & 2.89 & 0.96 \\
\hline \multirow{5}{*}{$\mathrm{C}$} & $\mathrm{C}_{1-3}$ & Control & \multirow{5}{*}{$\begin{array}{c}6 \% \\
\mathrm{Na}_{2} \mathrm{SO}_{4} \\
+3 \% \\
\mathrm{CaCl}_{2}\end{array}$} & 39 & 3.03 & 7.92 & 2.35 & 1.00 \\
\hline & $\mathrm{C}_{2-3}$ & $\mathrm{DM} 2, .25 \%$ & & 54 & 3.34 & 12.09 & 3.58 & 1.52 \\
\hline & $\mathrm{C}_{3-3}$ & SM-S,.25\% & & 59 & 3.80 & 15.02 & 4.45 & 1.90 \\
\hline & $\mathrm{C}_{4-3}$ & CM-B,.25\% & & 55 & 3.16 & 11.64 & 3.45 & 1.47 \\
\hline & $\mathrm{C}_{5-3}$ & SM-O,.25\% & & 45 & 3.50 & 10.55 & 3.13 & 1.33 \\
\hline
\end{tabular}

For group (B) of tested columns, the columns containing admixtures (SM-S \& CM-B) showed respectively a large increase of their energy absorption and ductility index of about $37 \& 45 \%$ over than that of the control column. The good influence occurs with 
admixture containing alkali wastes of cellulose paper industries (CM-B). But, column modified with the suggested admixture (SM-O) and control admixture (DM2) showed respectively a small decrease of their energy absorption and ductility index of about 4 $\& 10 \%$ lower than that of the control column.

For group (C) of tested columns, the columns containing admixtures (DM2, SM-S, CM-B \& SM-O)) showed respectively a large increase of their energy absorption and ductility index of about $52,90,47 \& 33 \%$ over than that of the control column. The good influence occurs with admixture containing alkali wastes of oil and cellulose paper industries (SM-S \&CM-B). This may be explained by the better influence of the suggested admixtures on increasing ultimate loads and longitudinal deformations of the tested columns under these aggressive conditions due to the improvement of their microstructure. Consequently, the energy absorption and toughness of these columns increased than the control ones.

\section{CONCLUSIONS}

Based on the results of the experiments carried out on normal strength R.C. columns containing in their compositions different admixtures from alkali wastes of oil and cellulose paper industries and hardened in different concentrations of sodium sulfate and calcium chloride solutions for a period of 7 months, the following conclusions can be drawn out:

1. Ultimate loads, stiffness, cracks, mode of failure and properties of the failure zone of the different groups of R.C. tested columns are significantly affected by the suggested admixtures and the concentration of sodium sulfate and calcium chloride solutions.

2. The final mode of failure of R.C.tested columns with the suggested admixtures was a shear failure with a small buckling of steel reinforcement accompanied by crushing with low explosive sound for the failure zone compared to the control column. The failure zone region of each column changed from the lower one-third to the upper one-third part depending mainly on the non homogeneity of concrete, type of admixtures and the concentration of sulfate and chloride solutions

3. The suggested admixtures (type SM-S \& CM-B ) reduced the height of the failure zone of tested columns by about $37 \& 29 \%$ for group (A), by about $22 \& 25 \%$ for group (B) and by about $35 \& 21 \%$ for group (C) respectively. They also reduced angle of the plane of shear failure ( $\theta$ ) by about $16 \& 11 \%$ for group (A), by about $8 \& 10 \%$ for group (B) and by about $8 \& 5 \%$ for group (C) respectively compared to the control column.

4. The columns hardened in high concentrations of sulfate $(6 \%)$ and chloride solutions (3\%) and modified with the suggested admixtures (typeSM-S, CM-B \& SM-O) showed a large increase in their ultimate loads by about $51,41, \& 15 \%$ respectively compared to the control tested column without admixtures. These admixtures, especially SM-S\& CM-B, also have a good influence on increasing ultimate loads by about $9 \% \& 2 \%$ respectively over than that with the control plasticizing admixture (DM2). 
5. The increase of the concentration of sulfate and chloride solutions from 3 to $9 \%$ had a neglected influence on reducing ultimate capacity of R.C. columns, after 7 months hardening in these conditions, modified with the suggested organic admixtures. But, this increase of concentration increased the reduction of ultimate loads for control columns without admixtures and with the control plasticizing admixtures (DM2) by about $14 \% \& 7 \%$ respectively.

6. The experimental values of ultimate capacity of tested columns, hardened in $(6 \%$ $\left.\mathrm{Na}_{2} \mathrm{SO}_{4}+3 \% \mathrm{CaCL}_{2}\right)$ is smaller than that calculated by Egyptian code by about 5 , 7, 6, \& 24\% for columns modified with suggested admixtures (DM2, SM-S, CMB\& SM-O) respectively. But, for control tested column without admixture, the experimental ultimate capacity is smaller than that predicted by about $13 \%$. But, the actual ultimate strength for column specimens modified with admixtures (DM2, SM-S, CM-B \& SM-O) increased respectively by about 44, 55, $44 \& 17 \%$ compared to the control column. The ultimate strength of R.C. columns containing admixture (SM-O) increased with the increase of sulfate and chloride solutions.

7. The ultimate longitudinal concrete strain of tested columns hardening in high concentrations of sulfate $(6 \%)$ and chloride solutions $(3 \%)$ and containing organic admixtures (SM-S, CM-B \&SM-O) decreased respectively by about 40, 24 \& $18 \%$. Also, the ultimate lateral concrete strain of tested columns containing organic admixtures (SM-S\& CM-B) decreased slowly by about $18 \%$ compared to the control column without admixtures. But, columns modified with the control admixture (DM2) and suggested admixture (SM-O) showed respectively an increase in their ultimate lateral concrete strain by about $83 \& 28 \%$ compared to the control ones.

8. The tested columns hardening in high concentrations of sulfate $(6 \%)$ and chloride solutions (3\%) and containing organic admixtures (SM-S, CM-B \& SM-O) showed respectively a clear decrease of their ultimate steel strain of about $36,73 \& 68 \%$ lower than that of the control column. Also, the columns containing these admixtures showed respectively a large increase of their concrete elastic modulus (Ec) of about 55, $44 \& 17 \%$ over than that of the control column.

9. The columns hardening in high concentrations of sulfate $(6 \%)$ and chloride solutions (3\%) and containing admixtures (DM2, SM-S, CM-B \& SM-O)) showed respectively a large increase of their energy absorption and ductility index of about $52,90,47 \& 33 \%$ over than that of the control column. The good influence occurs with admixtures containing alkali wastes of oil and cellulose paper industries (SMS \&CM-B).

10. The embedded steel bars of the control tested columns have a clear corrosion damage and its rate increases with high concentrations of sulfate and chloride solutions. But, in case of columns modified with admixtures, which contain alkali wastes from oil industries, the embedded steel bars have a little corrosion damage. In case of columns modified with admixture, which contains alkali wastes from cellulose paper industries, the embedded steel bars have a neglected corrosion damage for all different concentrations of salt solutions. 


\section{REFERENCES}

[1] Jackson, N., "Civil Engineering materials", The Macmillan press LTD, ch. 13, London, Third edition, 1983.

[2] M.D. Cohen, A. Bentur, "Durability of Portland cement, silica fume pastes in magnesium sulfate and sodium sulfate solutions", ACI Material Journal, Vol. 85, 1988, pp. 148-157.

[3] M.D. Cohen, " Theories of expansion in sulfoaluminate - type expansive cements", Cement and Concrete Research 13, 1983, pp. 809-818.

[4] D. Bonen and M.D. Cohen, "Magnesium sulfate attack on Portland cement paste: I. Micro structural analysis ", Cement and Concrete Research 22, 1992, pp. 169-180.

[5] M. Santhanam, M.D. Cohen and J. Olek, " Mechanism of sulfate attack: A fresh look", Part 1: Summary of experimental results, Cement and Concrete Research 32, 2002, pp. 915.

[6] R.S. Gollop, H.F.W. Taylor, "Micro structural and micro analytical studies of sulfate attack: I. Ordinary Portland cement paste", Cement and Concrete Research 22, 1992, pp. 1027.

[7] J. W. Wang, "Sulfate attack on hardened cement paste", Cement and Concrete Research 24, 1994, pp. 735.

[8] P.K. Mehta, "Magnesium sulfate attack on Portland cement concrete another look", Cement and Concrete Research 13, 1983, pp. 401.

[9] P.J. Tikalsky, R.L. Carrasquillo, " Influence of fly ash on the sulfate resistance of concrete", ACI Structural Journal, Vol. 89, 1992, pp.69.

[10] K. Torii, M. Kawamura, "Effects of fly ash and silica fume on the resistance of mortar to sulfuric acid and sulfate attack", Cement and Concrete Research 25, 1995, pp. 759-768.

[11] N. Smaouia, M. A. Bérubé, B. Fournierc, B. Bissonnetted and B. Durand, Effects of alkali addition on the mechanical properties and durability of concrete", Cement and Concrete Research, vol. 35, ISSUE 2, February 2005, pp. 203-212.

[12] Hegerovitsh, M.E., soloviev, V.E., and Tomashpolske, A.D., "Complex admixture for concrete mixes", A.C. No. 769212, USSR, Pub in B.E., No. 2, 1981.

[13] Batrakov V.G., Falekman V.R., and Venogradof U.M., "Perspective of producing and using admixtures for concrete and reinforced concrete", Journal of concrete and Reinforced concrete, No., 4, Moscow, 1989.

[14] Rashwan, M.M., "Improvement of the properties of concrete with hydrophopizing admixtures in hot and dry weathering conditions", Ph.D. thesis Eng - Akad. Alma-Ata, 1995.

[15] Rashwan, M.M., "Study of the possibility of producing new complex hydrophobizing admixtures for improvement of the cement materials properties “, Bulletin of the faculty of Engineering, Assiut University Vol .24, No.2, July 1996.

[16] Rashwan, M.M. and Sadeek, R.A., "Mechanical behavior of R.C. Columns As affected by a new complex hydrophobizing plasticizing admixture 'SMP', Bulletin of the faculty of Eng., Assiut University, Vol.27, No.1, January, 1999. 
[17] Rashwan, M. M., "An effective and direct method for protection of reinforced concrete elements from corrosion of steel", Journal of Engineering Sciences, Assiut University, Vol. 30, No. 1, pp. 63 - 83, January 2002.

[18] Rashwan, M. M. and Sadeek, R. A., "Mechanical behaviour of R. C. columns damaged by corrosion of reinforcement", Bulletin of the Faculty of Engineering, Assiut University, Vol. 25, No. 2, July, 1997.

[19] Jin-Keun Kim and Sang-Soon Lee, " The behavior of reinforced concrete columns subjected to axial force and biaxial bending", Journal of Engineering Structures, Issue 11, Vol. 22, pp. 1518-1528, November 2000.

\section{سلوك الأعمدة الخرسانية المسلحة المحتوية على مخلفات قلوية من المنتجات

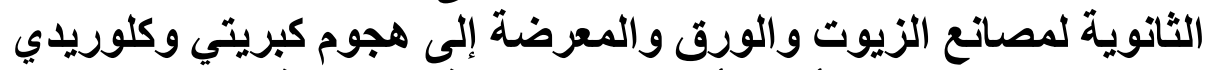 تحت تأثير الأحمال الاستاتيكية المحورية الئية}

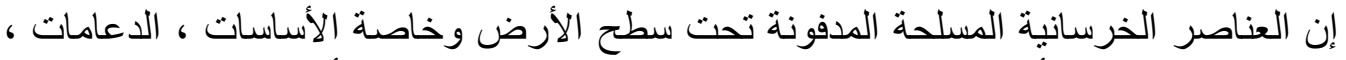

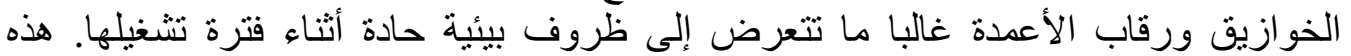

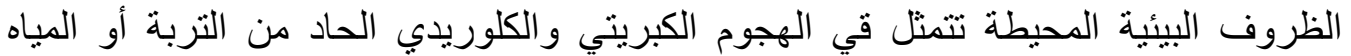

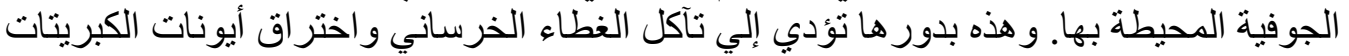

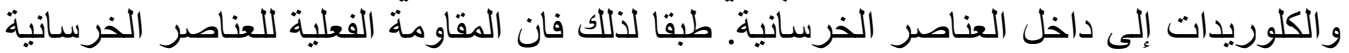

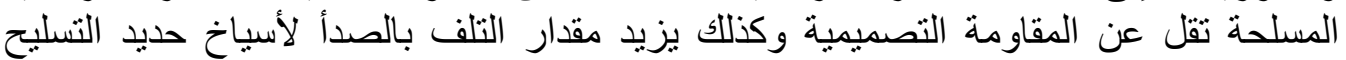

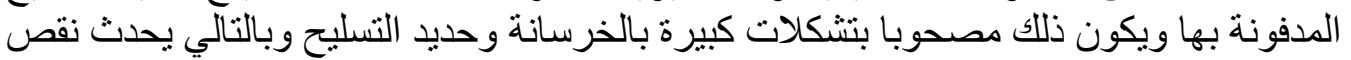
كبير في قوة تحمل هذه العناصر مع الزمن مما يقلل من العمر الافتر اضي للمنيح المنشأ.

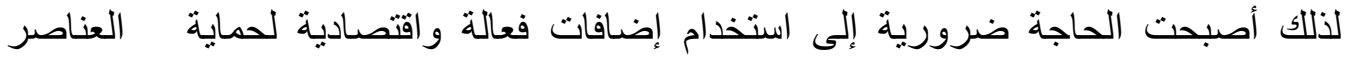

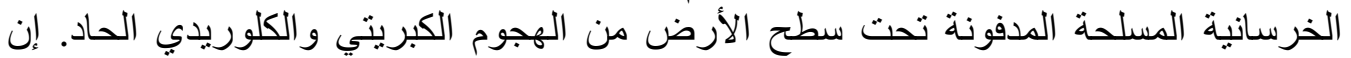

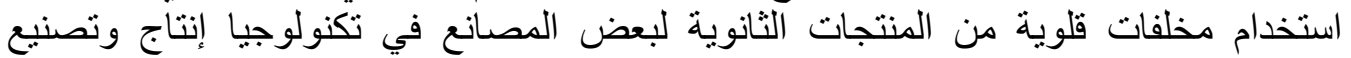
إضافات كيميائية ملدنة للخلطة الخرسانية ومحسنة لخو اص الخرساتة الخانة يمثل در اسة علمية ولية وعملية ضرورية خاصة من الناحية الاقتصادية ملة البرنية البيئية.

ولهذا فإن الغرض الرئيسي من هذا البحث هو عمل دراسة معملية لتحديد ميكانيكية تأثير

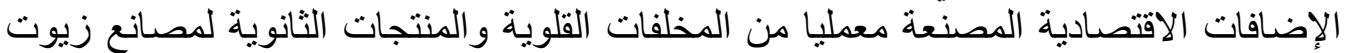

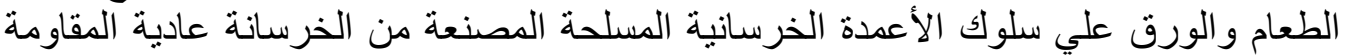

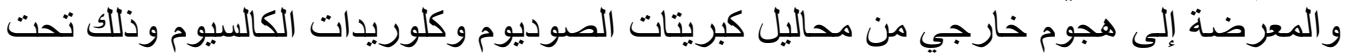

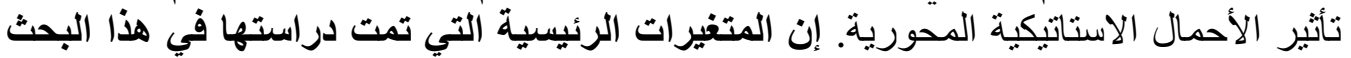

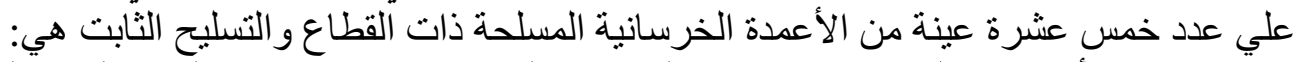

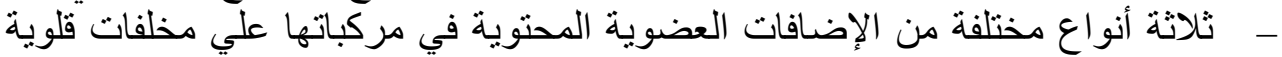

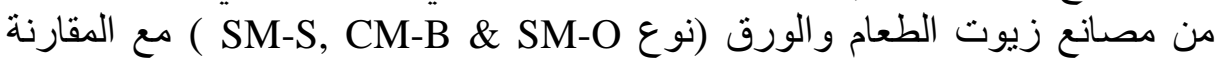
بعينة التحكم بدون إضافات وكذللك بعينة تحكم مع إضعافة ملدنة معروفة بالسوق المصري (نوع ADDICRETE DM2 ). 
- ـ ثلاثة مجموعات مختلفة من الأعمدة الخرسانية المسلحة المحتوية علي الإضافات

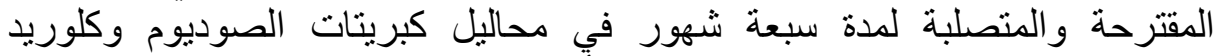

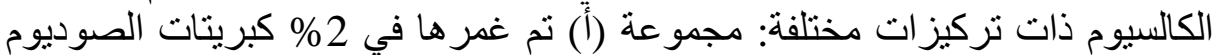

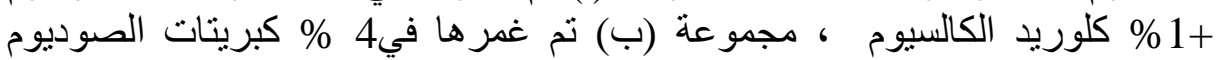

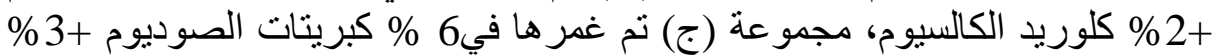
كلوريد الكالسيوم .

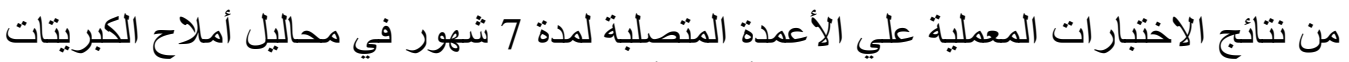

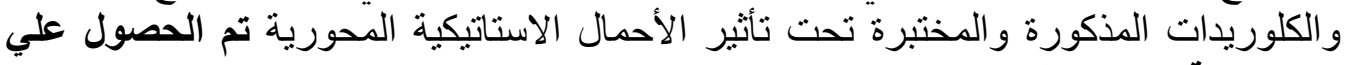

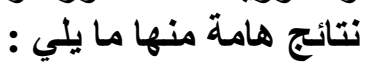

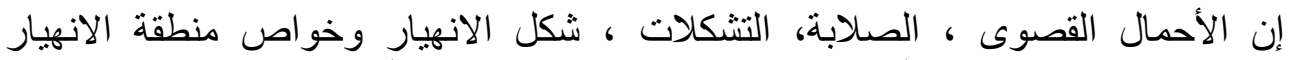

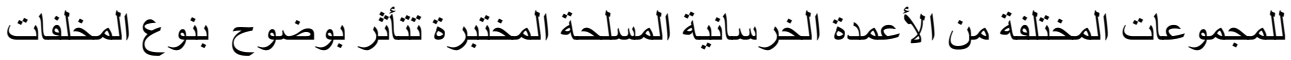

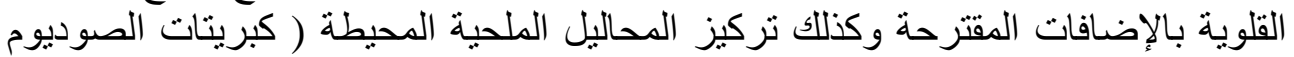

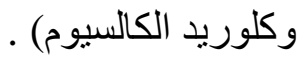
الأعمدة الخرسانية المسلحة المحتوية على هذه الإضافات (نوع SM-S, CM-B \& SM-O)

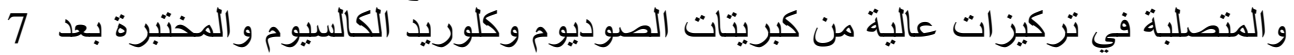

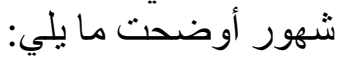

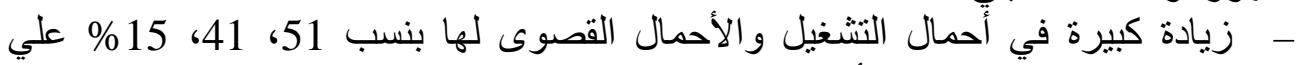

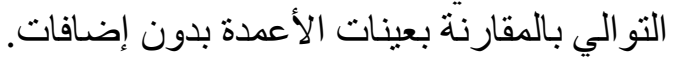

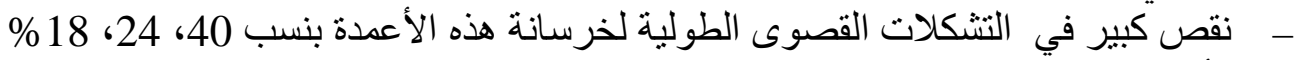

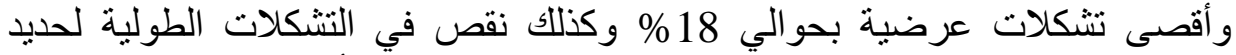

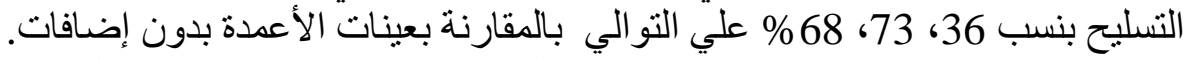

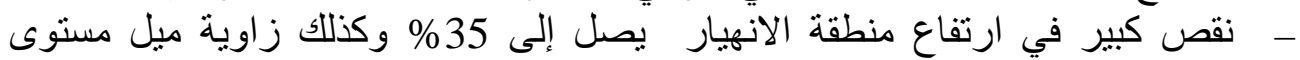

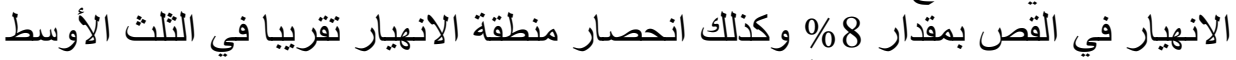

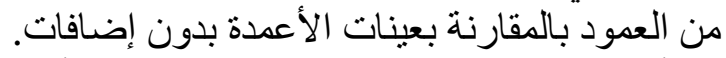

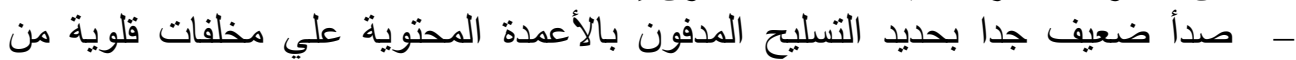

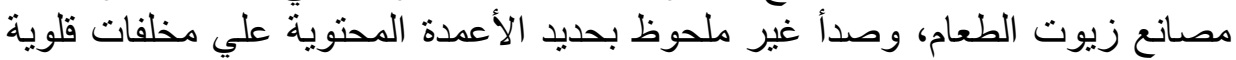

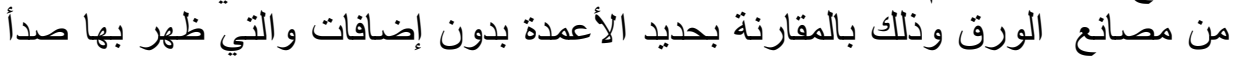

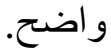
- زيادة كبيرة في المتانة لهذه الأعمدة معبرا عنها بكمية الطاقة الممتصة حتى حدوث

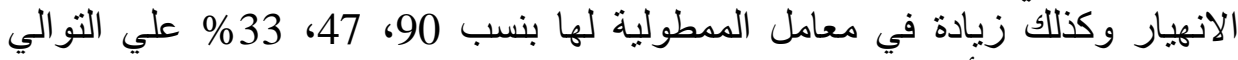

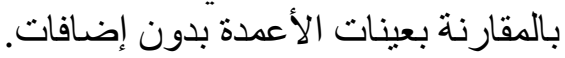

